\title{
KONTRREWOLUCYJNE POJĘCIE „POLITYKA HISTORYCZNA” W POLSCE
}

Michał Luczewski

Uniwersytet Warszawski

Przemiany pojęć są jednocześnie wskaźnikiem i składową przemian społecznych ${ }^{1}$. Stworzona przez Reinharta Kosellecka dyscyplina - semantyka historyczna - pokazuje, że nie można zrozumieć przemian społecznych bez przemian pojęć podstawowych. Pojęcia podstawowe strukturyzują debatę publiczną danej wspólnoty i dotyczą sfer dla niej kluczowych: polityki, kultury, ekonomii, społeczeństwa, nauki. Z biegiem czasu staja się one pojęciami powszechnymi, niezastępowalnymi, nieuniknionymi i jednocześnie kontrowersyjnymi. Wszystkie strony sporów politycznych są bowiem zmuszone do nich się odwoływać, niezależnie od tego, czy je afirmują, odrzucają czy też próbują stworzyć swoją własną definicję (por. Koselleck 2009: 67, 335-350). Ponieważ pojęcia podstawowe są ściśle powiązane $z$ daną wspólnotą i z jej długim trwaniem, nie poddają się łatwemu tłumaczeniu na inne języki (Koselleck 2009: 222).

Dla semantyki historycznej szczególnie ważne są innowacje językowe, które zmieniają naszą wizję przeszłości (naszą „przestrzeń doświadczenia”, czyli to, co pozostaje dla nas z przeszłości żywe) i wizję przyszłości (nasz „horyzont oczekiwań”, czyli to, co jest żywe z przyszłości; Koselleck 2001: 365). Jak wykazywał Koselleck, w nowoczesności horyzont oczekiwań zwiększa się nieustannie, a przestrzeń doświadczenia - zanika. W tym procesie dużą rolę odgrywają innowacje semantyczne, w wyniku których tworzą się pojęcia przyszłościowe (projektujące i planujące przyszłość), celowe (zakreślające cel działania) i sprawcze (prowadzące do działania

\footnotetext{
${ }^{1}$ Dziękuję za pomoc w pisaniu tekstu Kornelii Kończal i Joannie Wawrzyniak, a także dwóm anonimowym recenzentom oraz Jakubowi Motrence. Odpowiedzialność za ostateczny skutek tej pomocy spoczywa - oczywiście - na mnie.
} 
realizującego zakreślone cele). W tym sensie pojawienie się innowacji semantycznych dynamizuje rzeczywistość społeczną i często prowadzi do empirycznej realizacji pojęć (Koselleck 2009: 326).

Taki właśnie charakter - charakter innowacji semantycznej, która stała się pojęciem podstawowym - miało w Polsce pojęcie polityki historycznej (dalej: PH). Była to jedna $z$ najbardziej zaskakujących innowacji semantycznych, jakie miały miejsce w Polsce po 1989 roku, która wpisywała się jednocześnie w kontekst europejski (zob. François, Kończal, Traba, Troebst 2013, Kalicka, Witek 2014, Nowinowski, Pomorski, Stobiecki 2008). Spektakularna kariera czyni z niej ważny klucz nie tylko do rozumienia dynamicznych przemian społecznych III RP (zob. Dudek 2011: 34-35), ale także do rozumienia przemian nowoczesności (Assmann A. 2013, Szacka 2006).

Zanim „polityka historyczna” stała się pojęciem podstawowym, pojawiała się sporadycznie, podobnie zresztą jak niemieckie Geschicbtspolitik, od połowy XIX wieku. Pierwszym, który próbował wprowadzić to pojęcie do dyskursu publicznego, był Bronisław Trentowski (1843: 48-50). Otóż utożsamił on „politykę historyczną” z „historyzmem politycznym”, czyli wiarą, że „wszystko, co stare, dobre i święte jest bez warunku”. Taka polityka była - według Trentowskiego - niezdolna do stawienia czoła wyzwaniom nowych czasów. Powołując się na niemiecką filozofię dziejów i na zachodnią myśl polityczną, filozof domagał się od polskiej emigracji tworzenia własnych wizji przyszłości, które nie byłyby zakładnikami czasów minionych. Polityka historyczna stanowiła dla niego przykład reakcji i przeszkodę w zabezpieczeniu (naturalnych) praw człowieka, miłości bliźniego i prawdziwej polityki.

Mimo takich antecedencji polityka historyczna jako pojęcie nie istniała w polskim dyskursie publicznym. Po raz pierwszy pojawiło się ona jako innowacja semantyczna pod koniec lat 90. w niewielkim kręgu konserwatywnych intelektualistów, tworzących Warszawski Klub Krytyki Politycznej (dalej: WKKP; Stasik 2016)². Po kilku latach, kiedy stało się jednym z haseł Prawa i Sprawiedliwości, przeszło z marginesu do centrum życia publicznego i w bardzo krótkim czasie zaczęło to życie definiować. Podchwycenie pojęcia PH przez polityków prawicy uczyniło z niego pojęcie niezwykle kontrowersyjne, a w konsekwencji także - pojęcie podstawowe.

\footnotetext{
${ }^{2}$ Literatura na temat polityki historycznej w Polsce jest już niezwykle obszerna i bardzo dobrze opisuje pozycję członków WKKP (zob. Tokarz 2011, Traba 2010, Wolff-Powęska 2007), którzy jeszcze w połowie lat dwutysięcznych - wtedy, kiedy Prawo i Sprawiedliwość przejmowało pojęcie PH - w ogóle nie byli dostrzegani przez badaczy pamięci (zob. Śpiewak 2005).
} 
Wprowadzając „politykę historyczną”, członkowie WKKP czynili to w kontekście polemicznym wobec podejścia do historii charakteryzującego - według nich - III RP. W ich rekonstrukcji podejście to było, z jednej strony, podejściem estetycznym, zapominającym o przeszłości i nakierowanym na przyszłość (Cichocki 2005, Kostro, Ujazdowski 2005: 44-46), z drugiej zaś - podejściem krytycznym wobec przeszłości. Negatywnym punktem odniesienia stał się dla nich esej Jana Józefa Lipskiego Dwie ojczyzny, dwa patriotyzmy (1992: 139-164), który według nich legł u podstaw III RP z jej wizja „patriotyzmu krytycznego” i „historii krytycznej”, wpisujących się w paradygmat krytyki społecznej opisany przez Kosellecka (2015).

Esej Lipskiego, napisany w karnawale Solidarności, był krytyką bohaterszczyzny, megalomanii narodowej i ksenofobii. Miał on otworzyć historię na przyszłość (1992 [1981]: 146) i służyć zawiązaniu dobrosąsiedzkich stosunków, w tym zwłaszcza między Polską a Niemcami. Radykalizacja tego podejścia była dla środowiska WKKP książka Jana Tomasza Grossa Sasiedri, która przedstawiała Polaków jako współsprawców Holokaustu. Członkowie WKKP chcieli przeciwstawić takiej wizji historię bohaterską, która podkreśla momenty chwały narodu polskiego. Według Marka Cichockiego (2005), jednego z filarów WKKP, nastał czas, aby polityka historyczna wzmocniła wspólnotę polityczną. Dobrze te zamierzenia oddał Andrzej Nowak (2001), który w tekście Westerplatte czy Jedwabne opowiedział się za tym, żeby wspólnotę narodową kształtować nie na wspominaniu hańby (choć należy pamiętać o czarnych stronach historii narodu), ale na wspominaniu momentów, które świadczą o hołdowaniu najwyższym wartościom.

\section{/// Reżim nowoczesności}

Perspektywa czasowa właściwa nowoczesności zakłada następowanie nieskończonego postępu, co przekłada się na potoczne założenie, że przyszłość jest lepsza niż przeszłość (por. Krasnodębski 1991). W tym kontekście Aleida Assmann (2013: 19) wprowadziła pojęcie reżimu czasu nowoczesności, definiując „reżim czasu” (Zeitregime) jako nieuświadamiany, normatywny i bezalternatywny kompleks kulturowych wartości, które określają naszą postawę wobec czasu. W nowoczesności następuje, używając języka Kosellecka, singularyzacja, tzn. ujednolicenie dziejów: Wiele historii lokalnych składa się na jedną historię globalną. Dzięki temu możemy mówić o jednym, globalnym postępie, a nie o postępach. Semantyka historyczna Kosellecka pozwala nam na dalsze dookreślenie czasowej per- 
spektywy nowoczesności i wyróżnienie trzech, ściśle powiązanych ze sobą procesów, na których opiera postęp (zob. też Schmitt 1999).

1. Neutralizacja zła (moralny wymiar nowoczesności). W swojej klasycznej pracy, Krytykea i kryzys, Koselleck (2015) opisał proces oddzielenia polityki od moralności, w tym przede wszystkim od moralności odwołującej się do religii. W innych słowach opisywał ten proces Odo Marquard (2001), definiując nowoczesność jako proces odbierania złu znamion zła. To, co niegdyś było określane jako zło, w nowoczesności staje się czymś dobrym - i odwrotnie: to, co było dobre, staje się złe. Tak można rozumieć przekształcenie tradycyjnej, opisywanej przez Kosellecka wizji historii jako nauczycielki życia w wizję historii jako ciężaru (zob. Nietzsche 1996: 88-95, Wolff-Powęska 2011).

2. Neutralizacja transcendencji (wertykalny wymiar nowoczesności). W nowoczesności dramatis persona dziejów przestają być istoty transcendentne, jak Bóg, anioły i demony, a ich rolę przejmują ludzie. Cel ludzkiego życia przeniesiony zostaje z planu eschatologicznego w doczesność i to człowiek za swoje życie bierze pełna odpowiedzialność. Proces, który określa się jako immanentyzację (Voegelin 1992) czy też terrestrializację (np. Walicki 2011: 375), Koselleck opisywał jako ubóstwienie człowieka: „miejsce [Boga] zajmuje człowiek, który myśli Boga - to on staje się «ziemskim bogiem» i tym samym może sam rozumnie kierować swoją historią" (Koselleck 2009: 340). W konsekwencji dzieje są do dyspozycji człowieka i stają się - w języku Kosellecka - produkowalne. Inaczej niż los czy tradycje można kształtować je poprzez przewidywanie, planowanie i realizowanie planów. Wszechmoc zostaje odjęta Bogu, a staje się udziałem dziejów.

3. Neutralizacja kryzysu (czasowy wymiar nowoczesności). Kiedy zło i transcendencja zostaja zneutralizowane, zmienia się wizja dziejów. Według Kosellecka postęp, z jednej strony, niesie obietnicę przezwycię-

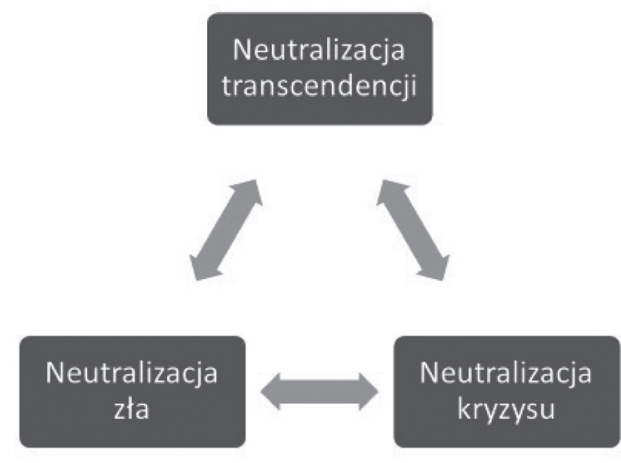

Ilustracja 1. Procesy nowoczesności 
żenia dawnego zła, które zostaje uczasowione (czyli przeniesione z poziomu metafizycznego w czas, w tym wypadku - w przeszłość), a z drugiej - zrealizowania dobra (które również zostaje uczasowione - tym razem przeniesione z poziomu metafizycznego w przyszłość). W tym kontekście niemiecki historyk wykazywał, że dla rozumienia nowoczesności kluczowe stało się pojęcie kryzysu (zob. Koselleck 2015). Otóż kryzys jest zeświecczonym odpowiednikiem apokalipsy, która nieustannie jest przesuwana coraz bardziej w przyszłość (Koselleck 2001: 64). W momencie, kiedy dzieje przestają być postrzegane jako arena walki dobra ze złem, a stają się areną odcinania się teraźniejszości od zła i realizacji dobra, które przychodzi z przyszłości, wizja kryzysu zostaje zastąpiona przez wizję postępu lub - gdy postęp został zrealizowany - wizję końca historii.

Ten potrójny proces - neutralizacji zła, neutralizacji kryzysu i neutralizacji transcendencji, które składają się na pojęcie postępu - Koselleck pokazuje na przykładzie podstawowego pojęcia nowoczesności: rewolucji (2001: 43-57). Nowoczesność zrywa z przeszłością, a w szczególności z chrześcijaństwem, aby zrealizować ideał w przyszłości; historia przestaje być nauczycielką życia. Rewolucja nowoczesna przynosi ze sobą „rzeczy nowe", jest totalna, dokonuje całkowitego przeobrażenia świata społecznego: gospodarki, polityki i kultury. Oddzielając teraźniejszość od przeszłości i otwierając przyszłość (Koselleck 2001: 249), nowoczesność generuje poczucie ruchu, dynamizmu i przyspieszenia czasu. Aby osiągnąć swój cel, rewolucja nowoczesna wymaga zaangażowania i łączy się z aktywizmem. Widoczne jest to w nowoczesnych pojęciach: -izmach, które mają charakter abstrakcyjny, mobilizujący, ideologiczny i upartyjniony (Koselleck 2001: 273). To wszystko można podsumować w następującej wizji postępu (Ilustracja 2).

Ilustracja 2. Kosellecka wizja postępu 


\section{/// Niemiecka i polska nowoczesność}

Zdaniem Kosellecka (2009: 235) w nowoczesności czas nieustannie przyspiesza, a przyszłość coraz szybciej staje się teraźniejszością. W takiej sytuacji przyszłość coraz trudniej przewidywać, a ona sama staje się źródłem nie nadziei, lecz niepewności. Kryzys, który miał być zneutralizowany przez nowoczesność, powraca. „Być może odpowiedź na kryzys - pisał niemiecki historyk - polega na poszukiwaniu stabilizatorów, które można odkryć w długim trwaniu dotychczasowej historii ludzkości. Może być tak, że kwestię tę da się sformułować nie tylko historycznie i politycznie, lecz również teologicznie" [podkr. - ME] ] $^{3}$ W tej perspektywie kryzys nowoczesności wiedzie do powrotu polityki, historii i teologii, a także dodajmy - do ich hybryd: polityki historycznej i teologii politycznej.

Ogólne rozważania Kosellecka na temat kryzysu nowoczesności można zastosować do konkretnych przypadków. Tak na przykład wolno interpretować empiryczne analizy Aleidy Assmann dotyczące Niemiec, w których kulminacją kryzysu nowoczesności okazał się przełom lat 80 . i 90. (2013: 281-312). Po pierwsze, jak w zgodzie z diagnozą Kosellecka wykazywała niemiecka badaczka, w Niemczech nastąił wtedy powrót (do) historii. Oto razem z upadkiem idei postępu historia zaczęła znów odzyskiwać swe znaczenie. Znów można było do niej powracać i uczyć się z niej. Po drugie, pojawiła się wtedy polityka tożsamości, a także polityka historyczna i jej nowe trendy (zob. także Assmann 2006). Po trzecie, towarzyszyło temu - według Assmann - pojawienie się nowych pojęć podstawowych: kultury, tożsamości, pamięci. Te trzy elementy składają się na przekształcenie klasycznej nowoczesności w coś, co autorka określa jako późną czy też zaawansowaną nowoczesność (Spätmoderne, Hochmoderne). Inaczej niż Koselleck, w analizie kryzysu nowoczesności niemiecka badaczka pominęła kwestie teologiczne, choć teologii politycznej poświęcony był klasyczny tom Jacoba Taubesa (2010), Teologia politycæna świetego Pawła, który zredagowała.

Jeśli porównać Polskę z Niemcami, to w naszym kraju odejście od reżimu czasowego nowoczesności i przejście do wysokiej, późnej nowoczesności zostało przesunięte o niemal dwie dekady. Czasowy reżim nowoczesności panował w naszym kraju jednak znacznie krócej: od 1989 roku

\footnotetext{
${ }^{3}$ Koselleck odwoływał się tu do teologicznej figury katechona, który ma zatrzymać kryzys nowoczesności (2009: 235). Oczywiście, podążał śladem Carla Schmitta, który za św. Pawłem mówił o katechonie jako o zasadzie, która powstrzymuje nadejście Niegodziwca, czyli Antychrysta (2 Tes, $2,7-8)$.
} 
do połowy pierwszej dekady XXI wieku. To wtedy zachodziły wszystkie nowoczesne procesy: neutralizacja zła, neutralizacja kryzysu i neutralizacja transcendencji ${ }^{4}$. Rok 1989 miał być rokiem rewolucji. Dla przedstawicieli nowych elit państwowych stanowił cezurę, która oddzielała III RP od tego, co minione i od czego powinniśmy się odciąć (wojna, zamknięcie systemu, PRL, religia, naród, autorytaryzm, gospodarka planowa, związki zawodowe), i która jednocześnie właściwym punktem odniesienia czyniła to, co nadchodzi (pokój, otwarcie systemu, Europa, świeckość, społeczeństwo obywatelskie, liberalizm, kapitalizm, przedsiębiorcy). Polskie elity zaczęły operować w typowo nowoczesnym paradygmacie, który Michael D. Kennedy (2002) określił jako kulturę transformacji (transition culture), neutralizującą i uczasawiająca zło (zamknięte w przeszłości) i uczasawiającą dobro (przychodzące z przyszłości). Ci, którzy wspierali tak rozumiana transformację, przedstawiani byli jako moralni, ci zaś, którzy nie akceptowali kierunku przemian - jako źli, sfrustrowani i nieprzystosowani do nowych czasów (Ost 2007). W konsekwencji kryzys PRL-u został przezwyciężony przez wizję postępu III RP. Te procesy znalazły swój wyraz w zmieniającym się pojęciu liberalizmu, jakie zaczęło funkcjonować w Polsce, i dostarczać ram interpretacji tamtych wydarzeń (Szacki 1991: 452-475, Szacki 1994). Jego treści nie określało już przeszłe doświadczenie (takie jak doświadczenie Solidarności; Hałas 1999), lecz przyszłe oczekiwania. W konsekwencji liberalizm wyznaczył dalekosiężny cel rewolucji i nadał jej nieodwracalny kierunek. Można ją spowalniać bądź przyspieszać, ale nie można jej odwrócić. Rewolucja stała się bezalternatywna, nie było miejsca na eksperymenty i poszukiwanie trzeciej drogi (zob. Koselleck 2001: 80). Jej najważniejszymi celami był „powrót do Europy”: wejście do politycznych (UE) i militarnych (NATO) struktur Zachodu (Horolets 2006).

Rewolucja 1989 roku uwidaczniała się w dwóch semantycznych innowacjach, jakie zrobiły karierę w III RP (Kurczewska 2002: 125-175, Śpiewak 2005, Tarkowska 1996). Pierwsza z nich była „gruba kreska” z exposé Tadeusza Mazowieckiego jako pierwszego niekomunistycznego premiera („przeszłość oddzielamy grubą linią). Choć Mazowieckiemu chodziło o to, żeby podkreślić, że jego rząd nie bierze odpowiedzialności za komu-

\footnotetext{
${ }^{4}$ Paweł Śpiewak zauważał, że w III RP polska myśl antytotalitarna nie została wykorzystana i przestała być źródłem inspiracji (2005: 15). „Polska wychodziła z komunizmu bogata w trudne doświadczenia, ale również w unikatową wiedzę na temat tego, czym był reżim sowiecki, na czym polegała pieriekowkea dusz i zniszczenie języka. [...] Polska myśl antytotalitarna, bez względu na to, czy rodziła się w kręgu pisarzy katolickich, czy intelektualistów świeckich lub wręcz ateistycznych, od perspektywy religijnej, w najszerszym sensie tego słowa, nigdy się nie oderwała. Wręcz wymagała, by problem człowieczeństwa postawić właśnie jako problem par excellence religijny".
} 
nistyczna przeszłość, a w szczególności działania poprzedniego komunistycznego rządu, z czasem to pojęcie zaczęło się odnosić do radykalnego zerwania z dziedzictwem komunizmu: dziedzictwem zniewolenia politycznego, ekonomicznego i moralnego. Druga innowacja semantyczna to „wybierzmy przyszłość”, która w 1995 roku stała się sloganem wyborczym zwycięskiego kandydata na prezydenta, Aleksandra Kwaśniewskiego (zob. Chwedoruk 2007). W tych dwóch pojęciach zawarte było doświadczenie oddzielania się od przeszłości i otwierania na przyszłość, tzn. ograniczanie przestrzeni doświadczenia i zwiększanie horyzontu oczekiwań, które według Kosellecka definiują nowoczesność.

\section{/// Nowoczesna kontrrewolucja}

Taka nowoczesna wizja dziejów stanowiła w Polsce wizję dominująca, choć od samego początku była krytykowana przez polską prawicę (Lipiński 2009, 2012). Co ciekawe, to właśnie prawica nadawała rezonans nowoczesnym pojęciom: „grubej kreski” (Śpiewak 2005: 113, m.in. Jarosław Kaczyński przekształcił „grubą linię” w „grubą kreskę”) i „wybierzmy przyszłość", podkreślając, że tworzą one złudzenia, że w rzeczywistości służą zachowywaniu ciągłości z dawnymi czasami, że - innymi słowy - nie są to $\mathrm{w}$ istocie pojęcia nowoczesne w służbie nowoczesności, ale pojęcia nowoczesne w służbie tradycjonalizmu. W języku Jerzego Szackiego (1971) powiedzielibyśmy, że tam, gdzie elity III RP wybierały w swoim własnym mniemaniu tradycję, tam ich przeciwnicy widzieli rzeczywiste trwanie dziedzictwa. Polska prawica zaproponowała więc rewolucję przeciw rewolucji 1989 roku (Matyja 2009b). Tego typu rewolucję można określić jako kontrrewolucję albo rewolucję konserwatywną.

Istotą kontrrewolucji było odwrócenie potrójnego procesu nowoczesności. Po pierwsze, występowała ona przeciw „etycznemu znijaczeniu” (Śpiewak 2005: 229), czyli neutralizacji zła i przeniesieniu zła w przeszłość. W ten sposób przywracała polityce moralność. Po drugie, w tej perspektywie zło było cały czas obecne i należało mu się bardzo mocno przeciwstawić. III RP nie realizowała zatem postępu, lecz tylko ukrywała rzeczywisty kryzys. Po trzecie, prawica odwoływała się do chrześcijaństwa, Kościoła i Solidarności pojętej jako ruch robotniczy i religijny - źródeł, od których odcięła się III RP. Tak przeciwstawiała się nowoczesnej neutralizacji transcendencji. Należy jednak zaznaczyć, że rewolucja konserwatywna nie była powrotem do status quo ante, była to rewolucja w imię przyszłości. Różnica polegała na tym, że o ile rewolucja nowoczesna, aby zrealizować przyszłe 
ideały, odcina się od przeszłości, o tyle rewolucja konserwatywna - do niej powraca.

Kontrrewolucyjna interpretacja III RP w zasadzie do 2005 roku (poza interludium w postaci rządu Jana Olszewskiego) nie zyskała w Polsce szerszego rezonansu. Podwójne zwycięstwo braci Kaczyńskich w wyborach parlamentarnych i prezydenckich w roku 2005 było możliwe, gdy ich wizja rzeczywistości uzyskała społeczną legitymizację w latach 2003-2005. Tamten okres Rafał Matyja (2009a: 310) określił jako „rewolucję semantyczną”. Składała się ona z dwóch elementów. Po pierwsze, do tej pory marginalizowana wizja III RP zaczęła z peryferii polityki gwałtownie przenikać do centrum (zob. Kwiatkowski 1990: 47), po aferze Rywina diagnoza Kaczyńskich dotycząca patologii polskiego państwa - korupcji, „zblatowania” elit, istnienia układu w postaci „grupy trzymającej władzę" - uzyskiwała coraz silniejsze poparcie. Jednocześnie po wejściu do Unii Europejskiej, które było głównym celem ideologów III RP, nie ma już wyraźnego punktu w przyszłości, do którego można by zmierzać. Paradoksalnie więc ich największy sukces był zarazem zapowiedzią najgłębszego kryzysu. Po drugie, w latach 2003-2005 pojawiły się nowe pojęcia opisujące i transformujące rzeczywistość. Najważniejszym z nich było pojęcie „IV RP”, z którego prawica uczyniła swoje hasło wyborcze (Borowiec 2013: 520-526). Pojęcie to wprowadzili Jarosław Kaczyński ${ }^{5}$ i Rafał Matyja (zob. artykuł Obóz Czwartej Rzeczypospolitej z 1998 roku; Matyja 2009b) pod koniec lat 90., ale zostało rozpropagowane przez Pawła Śpiewaka (2003) w artykule napisanym tuż po wybuchu afery Rywina i stało się przez pewien czas pojęciem podstawowym: niezbędnym i kontrowersyjnym (zob. Kornaś 2010). Było to jednocześnie pojęcie kontrrewolucyjne. Tak jak III RP chciała się odciąć od PRL-u "grubą kreską", tak IV RP chciała się odciąć grubą kreską od III RP. Zwolennicy IV RP uznali, że zerwanie z przeszłością w 1989 nie było dość radykalne, że przeszłość komunistyczna jako dziedzictwo wciąż ciążyła na teraźniejszości. Paweł Śpiewak, daleki od obozu Kaczyńskich i krytykujący jego partię, w swoim głośnym artykule zrealizował podwójny ruch rewolucji semantycznej: z jednej strony, wzmacniał semantyczną innowację Kaczyńskiego, a z drugiej - przejmował jego diagnozę:

\footnotetext{
${ }^{5}$ Wystapienie sejmowe Jarosława Kaczyńskiego z 18 lutego 1998 roku: „Można powiedzieć: III Rzeczypospolita nie wypełnia swojego elementarnego obowiązku i jeżeli to będzie trwało nadal, to z cała pewnością prędzej czy później przyjdzie czas, w którym będzie potrzebna Rzeczypospolita IV” (Kaczyński 1998).
} 
System polityczny Polski jest chory - pisał - podobnie jak chore są dziesiątki państw na wszystkich kontynentach. Okazało się, że ową chorobę przenieśliśmy razem $z$ instytucjami i personelem z PRL. [...] Polski kryzys jest przede wszystkim kryzysem politycznym, kryzysem zaufania. Bez kapitału społecznego nie zbuduje się rynku, sprawnej administracji. A przez ostatnie dziesięć lat dzieje się bardzo wiele, by pogłębić stan anomii. [...] Coś ostatecznie pękło i się skończyło. Rzecz nie może się sprowadzić do kolejnej fali moralistycznych pouczeń i rad. Niewiele wynika z narzekania i czarnowidztwa. Co najwyżej mogą zacierać ręce populiści i nacjonaliści, którzy będą zdobywać poparcie wraz z narastającym rozczarowaniem polską demokracja. Tymczasem bardzo wiele wskazuje na to, że III Rzeczypospolita wyczerpała swoje możliwości samonaprawy. Czas zacząć myśleć o IV Rzeczypospolitej (Śpiewak 2003) [podkr. - MŁ].

Paweł Śpiewak podkreślał tu ciagłość między PRL-em a III RP. W tej perspektywie zło wcale nie zostało zamknięte w przeszłości, lecz przedostało się do teraźniejszości, powodując głęboki kryzys, a nawet anomię. Nadszedł więc moment ostatecznego przesilenia. Śpiewak uczynił tutaj aluzję do Jacka Żakowskiego (1994), który na łamach „Gazety Wyborczej” pisał, że władze państwowe utraciły dawny etos. Żakowski spodziewał się, że ponieważ „,oś w Polsce pękło, coś się skończyło”, to „coś się musi wydarzyć”. Według Śpiewaka jednak nie tylko nic się nie wydarzyło, ale właśnie w tym czasie „pogłębiał się stan anomii” i to m.in. dzięki „Gazecie Wyborczej”: ani „Gazeta Wyborcza”, ani cała III RP nie były bowiem w stanie dokonać samonaprawy, co jest innym sposobem sformułowania tego, że utraciły legitymizację. Śpiewak jasno pokazywał, że coś „pękło ostatecznie" i należy stary system zastapić nowym. Treści hasła budowy IV RP nie mogła dostarczyć III RP, która okazała się katastrofa, lecz czerpać należało je z przyszłości. W języku Aleidy Assmann (2013) Śpiewak stał się tutaj wyrazicielem kryzysu (polskiej) nowoczesności.

W trakcie rewolucji semantycznej 2003-2005 obok hasła „IV RP” pojawiło się także hasło „rewolucji moralnej”. Podobnie jak „IV RP” zostało ono sformułowane przez Jarosława Kaczyńskiego (1996) w latach 90. i podobnie jak „IV RP” do przełomu 2003 roku nie osiagnęło ono dużego rezonansu. Zawierały się w nim wszystkie wątki, które według Assmann (2013) charakterystyczne są dla późnej nowoczesności: wezwanie do odbudowy kultury, tożsamości i pamięci. Wiązało się z nim podjęcie hasła 
polityki historycznej. Choć Warszawskiemu Klubowi Krytyki Politycznej, który to pojęcie wprowadził, bliska była myśl konserwatywna, jego członkowie nie chcieli w żadnym razie praktykować tradycjonalizmu. Nie chcieli konserwować przeszłości dla samej przeszłości, bo to by oznaczało konserwowanie III RP. Jednym z najpopularniejszych toposów w tym kręgu stały się ,zerwana nić tradycji” (Hannah Arendt) i „kontrrewolucyjne paradoksy" Jerzego Szackiego (1965), który opisywał sytuację, kiedy świat konserwatystów (de Bonald, de Maistre, Lammenais) po rewolucji znikną. Taka właśnie była sytuacja WKKP (np. Merta 2000: 31). Odwołując się do źródeł anglosaskich (Merta), niemieckich (Cichocki), francuskich (Gniazdowski) czy klasycznych (Karłowicz), członkowie Klubu na różne sposoby przedstawiali swoją wizję nowoczesnego - czy też raczej: późnonowoczesnego - rewolucyjnego konserwatyzmu w paradoksalnej sytuacji nowoczesności. Tomasz Merta w swoim programowym tekście, Nieodzowność konserwatyzmu, pisał: „Aby więc konserwatysta nie był rewolucjonistą (kontrrewolucjonista), nie może on domagać się wskrzeszenia tego, czego już nie ma, ani też tworzyć abstrakcyjnych projektów skoncentrowanych wyłącznie na tym, co powinno być. Konserwatysta nie może obrażać się na otaczający go, ciąle zmieniający się świat, zamiast tego powinien czynić starania, by zmianom tym nadać sens. Tak więc polski konserwatysta ma przed sobą wielka pracę krytyczną - musi wnikliwie przeanalizować dostępne mu tradycje, decydując, które z nich zasługują na jego poparcie" (Merta 2000: 31). Merta widział więc, że znalazł się w paradoksalnej sytuacji, w której nie można wrócić do przeszłości i nie można być już po prostu konserwatysta, lecz trzeba być konserwatystą krytycznym. Na ten sam paradoks wskazywał Marek Cichocki (1999) w pierwszej książce, w której przedstawił projekt „konserwatyzmu afirmatywnego" i zadawał pytanie: Czy konserwatyzm może nie być rewolucyjny? Cichocki (1999: 223) występował w niej przeciw tradycjonalizmowi i jako konserwatysta afirmatywny głosił wolność od „resentymentu wobec współczesności” i „akceptację nowoczesności”. Wreszcie Dariusz Karłowicz odkrywał w filozofii klasycznej „rewolucyjną negację”, którą ,uzupełnia, ale i uzasadnia tendencja konserwatywna, wyrażająca się w poszukiwaniu i dążeniu do odzyskania utraconej częściowo tożsamości. [...] Antyczny filozof jest więc zawsze zarazem kapłanem i buntownikiem, konserwatystą i zrewoltowanym szydercą" (Karłowicz 2007: 76).

Niezależnie od tego, czy projekt WKKP był określany jako konserwatyzm krytyczny, afirmatywny czy zrewoltowany, miał on wszelkie cechy rewolucji konserwatywnej. Był to konserwatyzm, który przeciw rewolucji nowoczesnej występował ze swoją własną rewolucją. Rewolucja konser- 
watywna pozostawała nowoczesna w swym geście kształtowania historii, a konserwatywna w tym, że do historii powracała. Jej nowoczesność polega na tym, że zrywała $z$ historią III RP, a konserwatyzm na tym, że powracała do historii długiego trwania: Solidarności, Powstania Warszawskiego, I Rzeczypospolitej etc.

W takim kontekście członkowie WKKP wprowadzili rewolucyjno-konserwatywne, czyli kontrrewolucyjne pojęcie „polityki historycznej”, które nawiązywało do przeszłości po to, żeby przysłużyć się przyszłości. PH w sposób jak najbardziej nowoczesny była pojęciem mobilizującym, dynamicznym, nakierowanym na przyszłość. Odpowiadała ona paradoksalnym formułom WKKP: „Przyszłość można wybrać, opierając się na przeszłości” (Merta 2008), należy połączyć „,wierność historycznemu dziedzictwu oraz pracę dla przyszłości” (Gawin, Kowal 2005: 13), „pamięć i nadzieję" (Merta 2005).

\section{/// Instytucjonalizacja pojęcia}

Warszawski Klub Krytyki Politycznej powstał w 1996 roku. Jego filarami byli Tomasz Merta, Marek Cichocki, Dariusz Gawin i Dariusz Karłowicz, a także - choć ich mniej zajmowały kwestie polityki historycznej - Paweł Paliwoda, Andrzej Gniazdowski, Robert Krasowski i Janusz Ostrowski. Ten ostatni nota bene wprowadził do polskiej debaty pojęcie „krytyki politycznej”, przejęte następnie i zinstytucjonalizowane przez polską lewicę w postaci pisma „Krytyka Polityczna”. Z kolei samo pojęcie krytyki było jednym z głównych pojęć prądów emancypacyjnych (Koselleck 2015). Choć pojęcie PH było wypracowane we wspólnych dyskusjach, wydaje się, że po raz pierwszy pojawiło się ono w artykule Dariusza Karłowicza, Pamieć i polityka z 1999 roku: „Łatwo się zgodzić z tezą, że polityka historyczna jest pięta achillesowa polskiej polityki zagranicznej” (Karłowicz 2004: 185). To pojęcie nie było wynikiem jakiejś pogłębionej debaty teoretycznej. „Nie mieliśmy z kim dyskutować, dlaczego wybrać «politykę historyczną», a nie np. "politykę pamięci»" - wspominał Karłowicz (2015). Od tego czasu mieliśmy do czynienia z niezwykle gwałtownym procesem, przypominającym epidemię czy rozprzestrzenianie się ognia, w którym pojęcie PH zajęło miejsce centralne. W języku teorii ruchów społecznych był to proces „zmiany skali” (scale shift; Tarrow, McAdam 2008: 347-373). Odpowiedzialność za niego ponoszą następujące mechanizmy: (a) przypisanie podobieństwa (PiS i WKKP podzielały podobną wizję świata); (b) połączenie ram (PiS i WKKP utworzyły jedną wizję świata); (c) dyfuzja 
relacyjna (zostały zbudowane więzi między członkami WKKP a PiS) oraz (d) wspólne działanie (WKKP i PiS zaczęły współpracować). Podstawowe podobieństwo między dwoma grupami polegało na tym, że podobnie jak Jarosław Kaczyński, członkowie WKKP dążyli do przeprowadzenia rewolucji konserwatywnej ${ }^{6}$, przy czym - jako intelektualiści - prezentowali oni bardziej rozbudowane diagnozy (zob. Stasik 2016). W ten sposób pojęcie PH ukute na marginesie polskiego życia publicznego przez grupę intelektualistów stworzyło razem z „rewolucją moralną” i „IV RP” konstelację „rewolucji semantycznej” 7 .

Pojęcie PH było wymierzone przez WKKP przeciw reżimowi czasowemu polskiej nowoczesności, a w szczególności przeciw neutralizacji moralności, kryzysu i transcendencji. Podobnie jak Jarosław Kaczyński (zob. Lipiński 2009, 2012) członkowie WKKP radykalizowali czasowy reżim nowoczesności, podkreślając, że w III RP doktryna „grubej kreski” i „wybierania przyszłości” obowiązywała bez wyjątków ${ }^{8}$. Zwolenników III RP przedstawiali jako tych, którzy chcą od przeszłości oddzielić się grubą linią, oni sami zaś dostrzegali raczej ciąłość III RP z komunizmem i chcieli powracać do przeszłości przedkomunistycznej bądź antykomunistycznej. Bardzo mocno również sprzeciwiali się neoliberalnemu naciskowi na modernizację i ekonomię, który zapanował w Polsce po 1989 roku. Wreszcie, dokonywali szeregu operacji, negujących procesy nowoczesności.

1. Moralny wymiar nowoczesności (amplifikacja zła). Krąg polskich intelektualistów sprzeciwiał się uczasowieniu zła. Marek Cichocki pisał na przykład: „To nie neutralizacja sądów moralnych jest ceną demokracji, lecz upadek demokracji staje się cena, jaką trzeba zapłacić za neutralizację sądów moralnych" (Cichocki 2000: 36).

\footnotetext{
${ }^{6}$ Choć rewolucję konserwatywną wiąże się z niemieckimi krytykami Republiki Weimarskiej (Kunicki 1999), od których członkowie WKKP bardzo stanowczo się odżegnywali (Gawin 2007: 199_ 216), to pojęcie to można uczynić bardziej abstrakcyjnym i odnieść do sytuacji polskich krytyków III RP.

${ }^{7}$ Daniel Grinberg podkreślał, że PH stanowiła część całej konstelacji pojęć: „Termin «polityka historyczna» zaczął funkcjonować w Polsce w połączeniu z całkiem realnymi zjawiskami politycznymi $-\mathrm{z}$ hasłami rewolucji moralnej i budowy IV RP [...]. Polityka historyczna w wypowiedziach jej głównych zwolenników ma być narzędziem przeprowadzenia tej rewolucji” (cyt. za: Leszczyński 2006a).

${ }^{8}$ Jak pokazały badania Elżbiety Tarkowskiej, wizja lat 90. jako „wyboru przyszłości” jest pewnym uproszczeniem. Jacek Kuroń twierdził na przykład: „Nie można budować przyszłości zapominając o przeszłości”, a Lech Wałęsa: „Nie wystarczy «wybrać przyszłość» [...]. Nie ma przyszłości bez wiedzy o przeszłości. Trudno sobie wyobrazić pomyślność bez sprawiedliwości - także tej, która sięga w czasy minione” (Tarkowska 1996: 18). Z kolei popularna na początku lat 90. koncepcja „przyspieszenia” nie oznaczała jedynie szybszego wprowadzenie reform i wyboru przyszłości, ale także rozliczenie się z przeszłością i funkcjonariuszami komunistycznymi (Śpiewak 2005: 78-103).
} 
2. 2. Wertykalny wymiar nowoczesności (amplifikacja transcendencji). Członkowie WKKP powracali do kwestii teologicznych. Ponieważ - jak to postrzegali - znaleźliśmy się w stanie kryzysu, którego sami nie możemy rozwiązać, na powrót ważna stawała się dla nich perspektywa transcendentna, metafizyczna i eschatologiczna. Dariusz Karłowicz pisał: „Jeśli kultura wyrasta z połączenia pamięci z absolutem, to kulturą nie może być nic, co jest pozbawione któregoś z tych dwu wymiarów" (2004: 181). W roku 2003 członkowie WKKP założyli rocznik „Teologia Polityczna”, podkreślając, że interesują ich ,sprawy polityczne widziane z perspektywy spraw ostatecznych",

3. Czasowy wymiar nowoczesności (amplifikacja kryzysu). Połączenie polityki z wartościami i odwołanie do transcendencji ukazało III RP jako państwo w bardzo głębokim kryzysie. Wbrew zwolennikom III RP członkowie Warszawskiego Klubu podkreślali, że pozycja naszej wspólnoty politycznej niebezpiecznie się obniżyła. $\mathrm{Na}$ arenie międzynarodowej jako symbol upadku komunizmu zaczą - jak wywodzili - funkcjonować nie zryw Solidarności, ale zburzenie Muru Berlińskiego, Polacy zaś zaczęli być widziani nie jako antykomuniści, ale jako antysemici. Zwieńczeniem tego procesu był według nich fakt, że na świętowanie upadku Muru władze niemieckie nie zaprosiły Lecha Wałęsy. Te zjawiska były główną motywacją artykułu Dariusza Karłowicza z 1999 roku, w którym PH pojawia się po raz pierwszy: „Tekst ten, nawiązując do dziesiątej rocznicy upadku komunizmu, był protestem przeciwko wypieraniu z pamięci Polaków i Europejczyków wkładu Solidarności” (Karłowicz, Łuczewski 2015). Według członków WKKP podobne negatywne skutki miała polityka zapomnienia o przeszłości na arenie wewnętrznej: osłabieniu bowiem uległa tożsamość, kultura i podmiotowość Polaków.

Członkowie WKKP, dla których polityka historyczna integralnie wiązała się z tworzeniem muzeów (zob. Karłowicz 2004: 187-188), spotkali się

\footnotetext{
${ }^{9}$ Była to jednocześnie cezura w rozwoju tego środowiska, albowiem tylko trzy osoby z WKKP - Dariusz Karłowicz, Marek Cichocki i Dariusz Gawin - zaangażowały się w nowy projekt. Jednocześnie członkowie WKKP dokonali przeniesienia pojęcia politische Theologie z obszaru niemieckiego, w który wprowadził je Carl Schmitt (2000). Podobnie jak pierwsze użycie „polityki historycznej”, pierwsze użycia „teologii politycznej” w języku polskim nie wiązały się jednak z wpływem niemieckim, lecz z polskim słowotwórstwem. Na przykład Stanisław Cat-Mackiewicz w felietonie Der weisse Fuchs, wydanym rok po Politische Theologie Schmitta, pisał: „W pamiętnikach hr. Wittego przede wszystkim dominuje jego teologia polityczna”, którą rozumiał jako odnoszący się do wszystkich ważnych sfer polityki zespół «silnych, trwałych przekonań»” (Cat-Mackiewicz 1972: 19).
} 
w 2003 roku z Lechem Kaczyńskim, który jako prezydent Warszawy stał się ich politycznym patronem i umożliwił zbudowanie Muzeum Powstania Warszawskiego. Budowę nadzorowała szefowa jego gabinetu politycznego, Elżbieta Jakubiak, dyrektorem został Jan Ołdakowski, warszawski radny Prawa i Sprawiedliwości, a wicedyrektorem - właśnie Dariusz Gawin. Najważniejsza publiczna prezentacja projektu PH została zorganizowana w 2004 roku podczas konferencji w sześćdziesiąta rocznicę Powstania Warszawskiego (Panecka 2005). We wstępnej fazie obrad Dariusz Gawin i Paweł Kowal wezwali do ustanowienia „polskiej polityki historycznej” i odtąd rozpoczęła się dynamiczna kariera tego pojęcia. Konferencja o polityce historycznej była publiczną prezentacją innowacji semantycznej wypracowanej przez WKKP, a jednocześnie miejscem, w którym konferencję zorganizowano: nowo powstałe Muzeum Powstania Warszawskiego stanowiło realizację polityki historycznej. Bardzo ważną rolę odegrał także tom Pamię́ i odpowiedzৃialność (2005), który zredagował Tomasz Merta razem z Robertem Kostro. Wśród autorów pojawia się późniejszy Minister Kultury i Dziedzictwa Narodowego, Kazimierz Michał Ujazdowski.

Powołanie Muzeum Powstania Warszawskiego stanowiło punkt zwrotny w dyskusjach o pamięci i - według powszechnej opinii - walnie przyczyniło się do zmiany nastawienia młodego pokolenia wobec przeszłości (Żychlińska 2009, Żychlińska, Fontana 2016). Polityka historyczna wpłynęła także zwrotnie na sytuację polityczną w Polsce. Sukces Muzeum Powstania Warszawskiego był jednym z elementów, który otworzył drogę do zwycięstwa prezydenckiego i parlamentarnego braci Kaczyńskich w 2005 roku. W następstwie tego ,polityka historyczna” stała się jednym z ideologicznych filarów nowo wybranych władz. Prawo i Sprawiedliwość (PiS), któremu doradzał Tomasz Merta, wpisało oficjalnie „politykę historyczną" do swojego programu wyborczego w 2005 roku (zob. Olszewski 2013: 81). Tomasz Merta został wiceministrem Kultury i Dziedzictwa Narodowego, odpowiedzialnym za realizację zobowiązania wyborczego Prawa i Sprawiedliwości do prowadzenia zewnętrznej i wewnętrznej polityki historycznej, w tym za budowę kolejnego muzeum: Muzeum Wolności, którego dyrektorem został współpracownik Merty, Robert Kostro, i flagowy program „Patriotyzm jutra” (zob. Leszczyński 2007).

Mimo utraty władzy przez PiS w 2007 roku i zatrzymania prac nad Muzeum Wolności, które zostało następnie przekształcone w Muzeum Historii Polski, pojęcie „,polityki historycznej” przeszło na stałe z dyskursu intelektualnego do dyskursu politycznego i państwowego. Zostało ono zinstytucjonalizowane przez Platformę Obywatelską, początkowo niechęt- 
ną tej semantycznej innowacji, w postaci specjalnego stanowiska rządowego: Premier Donald Tusk powołał Wojciecha Dudę, redaktora naczelnego „Przeglądu Politycznego”, na doradcę do spraw polityki historycznej w 2012 roku. W roku 2015 Prawo i Sprawiedliwość, które odniosło ponownie podwójne zwycięstwo w wyborach parlamentarnych i prezydenckich, wpisało do swojego programu „politykę historyczno-tożsamościową” i do wyborów szło z hasłem „systemowej polityki historycznej”. Ranga tego projektu została zwiększona przez fakt, że szef Rady Programowej PiS, Piotr Gliński, objął stanowisko Ministra Kultury i wicepremiera w nowo powołanym rządzie. Z kolei realizując swoje zobowiązania wyborcze, prezydent Andrzej Duda powołał Narodową Radę Rozwoju, a w niej sekcję „Tożsamość, kultura, polityka historyczna”. Ważnym elementem jej działalności było posiedzenie 16 lutego 2016 roku z udziałem prezydenta: „Polityka historyczna: konteksty, pomysły, realizacje”. Po kilkunastu latach od momentu, kiedy WKKP wprowadził pojęcie „polityki historycznej”, stało się ono pojęciem powszechnym, niezastępowalnym, nieuniknionym i kontrowersyjnym. W tym samym czasie pojęcie „IV RP”, które niegdyś było pojęciem podstawowym i z którego siłę czerpało pojęcie „polityki historycznej", zostało zmarginalizowane.

\section{/// Prehistoria pojęcia}

Kontekst, w jakim członkowie WKKP wprowadzali pojęcie PH, był podwójny: wewnętrzny i zewnętrzny. W polityce wewnętrznej było ono odpowiedzią na podkreślane przez nich zapomnienie o Solidarności i brak odpowiedniego jej upamiętnienia w 1999 roku, a także na debatę wokół $S_{q-}$ siadów Jana Tomasza Grossa, która wpisywała się w nurt polskiego patriotyzmu krytycznego, według WKKP podmywającego podstawy wspólnoty narodowej. W polityce zagranicznej polska PH miała być odpowiedzią na niemiecką PH (budowa Centrum przeciw Wypędzeniom) i rosyjską PH (kwestia katyńska). Z jednej strony, chcieli budować silną, polską tożsamość (kulturę, pamięć), a z drugiej - uczynić z Polski „aktywnego uczestnika” w jednoczącej się Europie (Gawin, Kowal 2005: 13). Ten podwójny wewnętrzno-zewnętrzny kontekst znalazł swoje odzwierciedlenie w ciekawym procesie semantycznym. Z jednej strony, Dariusz Karłowicz tworząc pojęcie PH, czynił to poprzez analogię z „polityka zagraniczną” czy „polityką kulturalną" W ten sposób realizował możliwość takiego połączenia, które istnieje w języku polskim i które przed nim nieraz już realizowano. Z drugiej strony, wewnętrzny kontekst transformacji pojęć połączył się

\section{/ 236 STANRZECZY 1[10]/2016}


z kontekstem zewnętrznym: dyfuzją pojęcia PH z obszaru niemieckiego (zob. Troebst 2014). Dariusz Gawin, wprowadzając to pojęcie do dyskursu publicznego, był przekonany, że było to tłumaczenie Geschitspolitik, jakiego dokonał Marek Cichocki na użytek polski ${ }^{10}$ (Friszke i inni 2011: 25, zob. też Troebst 2014), choć jednocześnie politykę historyczną stawiał obok ,polityki gospodarczej, socjalnej czy zagranicznej” (Gawin, Kowal 2005: 13). Był przy tym przekonany, ze pojęcie to w Niemczech utraciło początkowa negatywną konotację i stało się pojęciem neutralnym (Schmid 2009, Friszke, Gawin, Stobiecki, Wóycicki, Wiścicki 2011: 25). Z kolei Tomasz Merta stwierdził, że pojęcie „polityki historycznej” jest kalką z języka niemieckiego (cyt. za: Leszczyński 2006a). Na tym przykładzie widać, jak nałożenie się wewnętrznych i zewnętrznych źródeł pojęcia służyło temu, że stawało się ono pojęciem podstawowym: istniejącym już w Niemczech, a jednocześnie pojęciem zrozumiałym, bo zakorzenionym w kontekście polskim.

Trentowski sytuował pojęcie ,polityki historycznej” na antypodach nowoczesnego reżimu czasu. Radykalizm, podobnie jak „polityka historyczna”, był dla niego jednostronną wizją historii. Tak jak „polityka historyczna" skupiała się tylko na przeszłości, tak radykalizm skupiał się tylko na przyszłości:

Nie Wczoraj, lecz Jutro zamienia się w Dzisiaj - rekonstruował ten światopogląd Trentowski - nie martwa realność, lecz idea staje się co chwila rzeczywistością, a obumierająca rzeczywistość realnością. Przyszłość, ten święty skarbiec wszelkiej idealności, jest matką teraźniejszości rzeczywistej, a babką przeszłości realnej. [...] Nie przeszłość zatem, ta trumna życia, lecz przyszłość, kolebka idei, jest podwaliną, na której opiera się wszelki gmach polityczny. Komu nie poranne słońca przyszłości wschodzącej, lecz księżyc nocnej przeszłości jest polityczną gwiazda polarną; ten z natury rzeczy prowadzi naród, nie naprzód, ale w tył, i robi go bezcennym rakiem. Nie historyk, lecz prorok wiedzie tłumy za soba! (1843: 54-55).

I właśnie we fragmencie następującym po tej rekonstrukcji założeń radykalizmu Trentowski wprowadził interesujące nas pojęcie:

\section{Polityka historyczna, to gawęda o rzeczach dawno ubiegłych słabego i niepojmującego dzisiejszości, nudnego, śmieszne- go, a przecież zarozumiałego starca. $\mathrm{O}$, nie szukaj życia w ka- takumbach grobowych! Tu są li mary i upiory; tu panuje duszące}

${ }^{10}$ Sam Cichocki zaś woli mówić, że pojęcie to powstało podczas wspólnych dyskusji WKKP (Cichocki, Luczewski 2015) 
powietrze, w którym gaśnie pochodnia i wszelkie światło" (1843: 54-55). [podkr. - MŁ]

Trentowski odrzucał zarówno politykę historyczna, jak i radykalizm - i szukał jakiejś syntezy między nimi, proponując "filozofię polityczna”, która tworząc teraźniejszość, czerpałaby zarówno z przeszłości, jak i przyszłości. (Zauważmy na marginesie, że właśnie „filozofia polityczna” jest najbliższa współczesnemu rozumieniu „polityki historycznej”). Żadna z jego semantycznych innowacji jednak się nie przyjęła. W wieku XX pojęcie „polityki historycznej” pojawiało się już poza kontekstem filozofii dziejów. Znaleźć je można było sporadycznie w dyskursie naukowym, np. w historii, gdzie stało się ekwiwalentem ,historii politycznej”. W tym duchu na przykład wybitny historyk, Władysław Konopczyński, odnosił ja do działań obozu stańczyków: historyków polityki i zarazem polityków historii (1921: 10). Pojawiała się też w filozofii w kontekście marksistowskiej wizji emancypacji (Kuczyński 1972: 201).

\section{/// Głębokie warstwy}

W każdym pojęciu zawarte są głębokie warstwy czasu (Koselleck 2012). W języku polskim „polityka historyczna” czerpie z głębokich warstw znaczeń dwóch składających się na nie pojęć: „polityki” i „,historii”, które posiadają znacznie dłuższy, antyczny rodowód, a ich znaczenie różni się od znaczenia dwóch pojęć składających się na Geschichtspolitik: Geschichte i Politik.

Po pierwsze, jak wiadomo, ,polityka” została powiązana przez Arystotelesa z roztropną troską o dobro wspólne. Autorytet Arystotelesa był tak duży, że w nowożytności korzystano z jego pojęcia „polityki”, ale w istocie coraz częściej odwoływano się do samego słowa z jego semantycznymi potencjałami, a znaczenie pojęcia ulegało daleko posuniętej transformacji. Z jednej strony, polityka była coraz częściej utożsamiana z pragmatyzmem, realizmem, z polityką partyjną, które nie bierą pod uwagę wartości, lecz interes (Koselleck 2009: 428). Z drugiej strony zaś, pozytywne skojarzenia $z$ dobrem wspólnym zostały przeniesione z polityki na społeczeństwo obywatelskie, ponieważ Arystotelesowska koinonia politike została przetłumaczona jako societas civilis (zob. Koselleck 2009: 93-94). Ten proces był szczególnie silny w Polsce, gdzie podobnie jak w Rosji (Steinmetz 2007: 12) polityka otrzymuje niezwykle negatywną konotację. $Z$ tego powodu możliwe było, że jedna z polskich partii politycznych szła do zwycięskich wyborów z hasłem „Nie róbmy polityki”. Choć podobna ewolucja zaszła 
w niemieckiej Politik, to Niemcy zachowały jeszcze pojęcie równoległe, das Politische („to, co polityczne” / „polityczność”), które przechowywało Arystotelesowskie, moralistyczne skojarzenia, nieobecne w języku polskim.

Po drugie, w języku polskim historia odnosi się przede wszystkim do dyscypliny naukowej, bezstronnego opisu przeszłości, i ma inne znaczenie niż niemiecka Geschichte, które w naszym języku oddawane jest jako „dzieje”. To teoretyczne znaczenie historii, które dotyczy warunków możliwości poznawania samej historii jako ciagu zdarzeń, jest stosunkowo późnej daty i pochodzi z przełomu XVIII i XIX wieku (Koselleck 2009: 76). Mimo że historia-przeszłość i historia-nauka tworzą jedno pojęcie, coraz silniejszy nacisk kładziono na historię jako naukę. Ten proces był jeszcze wzmacniany przez opisywany przez Kosellecka pozytywistyczny mit, że historia jest nauką nieideologiczną i niepolityczna, która opisuje dzieje w sposób obiektywny (Koselleck 2009: 76). Na proces rozchodzenia się „historii umoralniającej” i , „historii wyjaśniającej” zwracał uwagę Stefan Czarnowski (1956: 121), choć pojęcie historii stosował nadal do wszystkich form opowiadania o przeszłości i do samej przeszłości (1956: 99-102). Podobnie czyniła także jego uczennica, Nina Assorodobraj-Kula (1995: 862-865).

Różnica między Geschichte (dziejami) a historią uwidacznia się bardzo mocno u Augusta Cieszkowskiego (Walicki 1970: 99-88), filozofa współczesnego Trentowskiemu, który jako autor oryginalnej filozofii czynu (Philosopbie der Tat), ogniwa łączącego Hegla z Marksem, na trwałe wpisał się do historii filozofii zachodniej. W analizach Kosellecka (2001) pojęcie dziejów (Geschichte) jest kluczowe. Nosi ono bowiem w sobie istotę nowoczesnych, dynamicznych przemian: singularyzację, uczasowienie, wszechmoc, produkowalność i rewolucyjność. Najbardziej dojrzały i refleksyjny wyraz tych przemian stanowi według Kosellecka (2001: 95-105) Geschichtsphilosophie. To właśnie filozofia dziejów była według niego odpowiedzialna w największym stopniu za stworzenie reżimu czasowego nowoczesności. Zawarty był w niej aktywizm, bardzo zbliżający jej znaczenie do znaczenia późniejszego Geschichtspolitik. Innymi słowy w Geschichtsphilosophie tkwił już potencjał Geschichtspolitik. Paradoks Cieszkowskiego polegał na tym, że stał się on jednym z klasyków europejskiej filozofii dziejów (Geschichtsphilosophie), choć próbował wprowadzić na jej miejsce pojęcie przeciwstawne: Historiosophie, „historiozofię” (które zaczerpnął nota bene od Józefa Hoene-Wrońskiego, twórcy pojęcia „mesjanizm”, spopularyzowanego następnie przez Adama Mickiewicza). „Historiozofia” u Cieszkowskiego występowała przeciw radykalizmowi Geschichtsphilosophie. Utrzymując singularyzację dziejów, Cieszkowski starał się ograniczyć ich produkowalność (zostawiając miejsce dla 
ingerencji Boga i Ducha Świętego), rewolucyjność (zastępując ją ewolucyjnością i łącząc nowoczesność z chrześcijaństwem), uczasowienie (nie przekreślając eschatologii) i wszechmoc (nie przecząc możliwości metafizyki). Semantyczny potencjał rewolucyjności, uczasowienia, wszechmocy i produkowalności był w historiozofii znacznie niższy niż w filozofii dziejów. I to właśnie z tego powodu pojęcie filozofii dziejów, lepiej współgrając z nowoczesnymi przemianami, stało się pojęciem podstawowym, marginalizując innowację językową Cieszkowskiego, choć jej nie eliminując. Poprzez analogię z historiozofią można powiedzieć, że „polityka historyczna” osłabia rewolucyjność Geschichtspolitik, która na polski powinna być przekładana jako „polityka dziejów”.

\section{/// Redefinicja polityki i historii}

Kiedy WKKP zaczął głosić potrzebę „polityki historycznej”, wymagało to poważnej semantycznej pracy, a w szczególności - redefinicji pojęć „polityki” i ,historii”. Jeśli bowiem utrzymano by znaczenie polityki jako Realipolitik (Steinmetz 2007), a historii jako pozytywistycznej nauki, opowiadającej o tym, wie es gewesen war, to próbowano by połączyć w jednym pojęciu roszczenia, których nie można połączyć: roszczenie do władzy i roszczenie do prawdy. Świadom był tego np. Tomasz Merta, który w debacie z Jerzym Jedlickim podkreślał, że pojęcie PH nigdy nie wydawało mu się „Szczególnie szczęśliwe. Już samo słowo «polityka» - mówił - ma bardzo negatywne konotacje, bo sprowadzane jest często do cynicznej gry. Trudno też zapomnieć, jaki użytek z historii czyniła władza w okresie PRL. «Polityka historyczna» w bardzo wielu uszach brzmi więc tak, jakby chodziło o manipulowanie historia. Zamiast rozmawiać o istocie rzeczy, trzeba się więc tłumaczyć z samego pojęcia” (cyt. za: Leszczyński 2006a).

Przekształceniu ,polityki historycznej” w pojęcie pozytywne nie sprzyjały same działania WKKP. Kiedy Marek Cichocki przetłumaczył książkę Carla Schmitta (2000), nota bene nauczyciela Reinharta Kosellecka i inspiratora semantyki historycznej, całe środowisko musiało się liczyć z tym, że automatycznie będzie łączone z agonistyczną wizja polityczności Schmitta (Leszczyński 2006b, Traba 2010). Jego kluczowe znaczenie w semantyce historycznej polegało na tym, że przedefiniował on w języku niemieckim pojęcie polityczności, które do jego czasu wciąż posiadało moralistyczne, Arystotelesowskie potencjały semantyczne. Schmitt nie tylko sprowadził je do pozbawionego odniesień do norm i wartości pojęcia „polityki”, lecz także nadał mu jeszcze bardziej radykalny sens niż „polityka”. W klasycz- 
nym sformułowaniu stwierdził: „Specyficznie polityczne rozróżnienie, do którego można sprowadzić wszystkie polityczne działania i motywy, to rozróżnienie przyjaciela i wroga" (Schmitt 2000: 254). W polityczności nie chodziłoby już tylko, jak w polityce, o realizację interesu, ale o walkę z wrogiem, która może przeistoczyć się w wojnę na śmierć i życie. W ten sposób, czego zresztą Schmitt był świadom, pojęcie polityczności nabywało u niego jeszcze bardziej radykalnej konotacji niż polityka. Wkraczając do polskiego dyskursu publicznego z ,koronnym jurysta III Rzeszy” i jego pojęciem polityczności, członkowie WKKP wzmacniali w ten sposób negatywne skojarzenia z polityka. W konsekwencji np. historyk Robert Traba, rekonstruując projekt polityki historycznej (którą określał jako „nową politykę historyczną”), podkreślał, że charakterystyczny dla niej jest „sposób «konstruowania wroga» oparty na uproszczonej interpretacji filozofii Carla Schmitta. Zakłada ona genetyczny podział ludzi na «wrogów» i «przyjaciół». W tym dychotomicznym świecie spełniać ma się sens ludzkiej egzystencji”" (2010: 301).

O różnicy między polskim i niemieckim kontekstem świadczy fakt, że w wydawnictwie „Teologii Politycznej” opublikowano przetłumaczona przez Marka Cichockiego klasyczna pracę Christiana Meiera, Powstanie polityczności u Greków (2012). Christian Meier (1987) wprowadził negatywne pojęcie Geschichtspolitik do niemieckich debat, ale nie przeszkadzało mu to mówić w pozytywnym kontekście o polityczności Greków, które to pojęcie dodatkowo przedefiniowywal w stosunku do Schmitta jako przezwyciężenie antagonizmu między wrogiem a przyjacielem i stworzenie władzy (2012: 21). W ten sposób Meier powracał do Arystotelesowskiej wizji polityki. I właśnie tym tropem, a nie tropem Schmitta, szli członkowie WKKP. W swojej pozytywnej wizji polityczności powracali nie tyle do Schmitta, ile przede wszystkim do tradycji klasycznej, Grecji i Rzymu. Powracając zaś do tradycji klasycznej, poszukiwali wsparcia u takich myślicieli, jak Hannah Arendt, Leo Strauss, Michael Oakeshott, Eric Voegelin, Alasdair MacIntytre, amerykańscy paleokonserwatyści, francuscy i angielscy kontrrewolucjoniści (zob. Cichocki, Merta 2000). Jak wspominał Dariusz Karłowicz:

Polityczność nie była negatywnie nacechowana. Dla nas to był kontekst Arystotelesa «wspólnoty politycznej». Nasze środowisko wyrosło ze wspólnej lektury św. Augustyna, Platona i Arystotelesa, Cycerona i Jana Pawła II. Czytaliśmy też Hobbesa, Locke’a i Johna Graya, bo byliśmy krytyczni wobec liberalizmu. Tak rozumiana polityczność dawała nam zdolność analizowania rzeczywistości 
przeciw redukowaniu polityki do ekonomii i głoszenia haseł „końca historii” (Karłowicz, Luczewski 2015).

Jednocześnie z redefinicja polityki i przywróceniem jej pozytywnego znaczenia członkowie WKKP musieli przedefiniować „historię” i ująć ją nie jako dyscyplinę naukową, ale jako rzeczywistość społeczną, która ma znaczenie dla teraźniejszości. Chodziło o to, żeby poszerzyć „przestrzeń doświadczenia” i uczynić przeszłość na powrót żywą. Kluczowa jest tutaj metafora żywej historii. Wprowadziła ją do języka naukowego Nina Assorodobraj-Kula (1995) w klasycznym artykule: Żywa historia, w którym miała na myśli różne postaci „społecznego zawłaszczania czasu minionego czy wyobrażeń o nim” (1995: 856). W języku Szackiego (1971) powiedzielibyśmy, że przeszłość musi zostać upodmiotowiona, że musi stać się tradycją. Zwracal na to uwagę Marek Cichocki: historia jest tylko strumieniem martwych zdarzeń, który może zostać dopiero ożywiony przez pamięć historyczną (Cichocki 1999: 11). Zauważmy na marginesie, że taki sam problem poszerzenia „przestrzeni doświadczenia”, ożywienia historii był obecny te ż w Niemczech: „Czy historia jeszcze do nas przemawia, czy jeszcze nas dotyczy, skoro pochylamy się nad nią beznamiętnie jak nad zielnikiem i bez najmniejszego oburzenia rejestrujemy, co dzieje się na tym gruncie" - pytał Siegfried Lenz (cyt. za: Wolff-Powęska 2011: 368). Nie każda pamięć czyni przeszłość żywa, tylko ta pamięć, która łączy przeszłość z tym, co jest dla nas najważniejsze dziś, a więc z naszymi wartościami. Nie można się więc dziwić, że Karłowicz (2004) wprowadził w tym kontekście pojęcie pamięci wspólnotowej czy też „pamięci aksjologicznej”. Ta językowa innowacja nie zyskała jednak rezonansu.

Członkowie WKKP przeciwstawiali się postulatowi zostawienia historii historykom, który równoznaczny był dla nich z ograniczeniem znaczenia historii tylko do historii jako dyscypliny i był tylko inną formą artykulacji nowoczesnej rewolucji, która odcina się od przeszłości i przestaje traktować ją jako nauczycielkę życia. Dlatego dla WKKP atrakcyjne były intuicje Hansa-Georga Gadamera, który podkreślał ciagłość dziejów (Gadamer 2007). To miał na myśli Dariusz Gawin: „Kiedy słyszę, że historię trzeba zostawić historykom, mam skojarzenie z martwym ciałem, które trzeba oddać patologom do prosektorium. Niech sobie je kroja, zamykaja w słoiki i oglądaja pod światło. A przecież to jest żywe i wciąż strasznie ważne" (cyt. za: Legutko 2014).

Redefiniując „politykę” i „,historię”, członkowie WKKP otwierali pole do połączenia ich w ,polityce historycznej”. Aby ta przemiana semantyczna 
była możliwa, musieli jednocześnie podkreślać, że są świadomi możliwych niebezpieczeństw upolitycznienia historii. Jak wspominał Dariusz Karłowicz: „To, jak wspólnota zapamiętuje swoja przeszłość, opowiada o tym, jaką chciałaby być dziś i w przyszłości. [...] Nie oznacza to oczywiście, że historię można sobie wymyślać tak, by realizowała jakieś zamówienie choćby polityczne. U korzeni musi być prawda. Musi być świadectwo, i to świadectwo zapamiętane, zrozumiane i uznane za swoje" (cyt. za: Legutko 2014).

Członkowie WKKP szli droga rewolucji, ale rewolucji konserwatywnej, jednocześnie ograniczając rewolucyjne sugestie zawarte w pojęciu dziejów. Inaczej bowiem niż w dziejach, w „historii” nie jest zawarty tak silny potencjał semantyczny ,singularności” (członkowie WKKP przeciwstawiali się wyobrażeniu, że dzieje są jedne i mają jeden kierunek, istnieje raczej wiele partykularnych historii), ,produkowalności” (historii nie da się dowolnie tworzyć), „uczasowienia” i „wszechmocy” (nie wszystko dzieje się w czasie, należy wziąć pod uwagę również perspektywę spraw ostatecznych).

\section{/// Przemiany semantyczne}

Żeby polityka historyczna stała się pojęciem podstawowym, musiały zostać zmarginalizowane jej potencjalne ekwiwalenty. W 1999 roku, tym samym, w którym Dariusz Karłowicz wprowadził pojęcie polityki historycznej, ukazało się polskie wydanie książki Norberta Freia (1996), Vergangenheitspolitik. Die Anfänge der Bundesrepublik und die NS-Vergangenheit. Pojęcie Vergangenheitspolitik zostało początkowo przetłumaczone w sposób opisowy: „polityka wobec przeszłości” i nie zyskało dużego oddźwięku poza wąskimi kręgami germanistów i historyków. Miało się to zmienić, gdy w 2003 roku użył go Zdzisław Krasnodębski (2003: 229 i n.) w swojej głośnej książce Demokracja peryferï, poświęcając mu cały rozdział. Mimo jednak tego, że sama książka rozpoczęła szeroką debatę w Polsce, pojęcie „polityki wobec przeszłości” nie przyjęło się. Debata publiczna, jaka miała miejsce wokół książki Krasnodębskiego, nie przełożyła się na debatę polityczna. Kiedy w tym samym czasie Lech Kaczyński zaangażował się w budowanie Muzeum Powstania Warszawskiego, używał już pojęcia „polityki historycznej”. W konsekwencji stało się ono pojęciem nie tylko politycznym, lecz dosłownie partyjnym. „Polityka historyczna” stała się w ten sposób Kampfbegriff, generującym konflikty i trwale związanym z polityką prawicy. Sam Krasnodębski zaczął się też tym pojęciem bardzo szybko 
posługiwać (zob. Panecka 2005). Uzyskało ono także wsparcie ze strony uznanych naukowców (zob. też Roszkowski 2005).

O ile w Niemczech nastapiło stopniowe przejście od upolitycznienia do odpolitycznienia, od przypisania polityki historycznej pewnym grupom do konstatacji, że wszystkie grupy ją uprawiają, od konkretnego do abstrakcyjnego znaczenia (Troebst 2014), o tyle w Polsce ci, którzy zaczęli tego pojęcia używać, upolitycznili je, przypisując politykę historyczną własnej grupie i nadając jej konkretne znaczenie. Upartyjnienie terminu i ustawienie go w polemicznym kontekście wobec lewicy i liberalizmu doprowadziło do silnej reakcji negatywnej ze strony liberałów i lewicy. Upraszczając, powszechne wrażenie było takie, że „polityka historyczna” stała się w gruncie rzeczy polityką Lecha i Jarosława Kaczyńskich, wymierzoną w III RP (Wolff-Powęska 2007).

Upartyjnienie, kontekstualizacja i przypisanie do grupy spowodowały, że w dyskursie akademickim traktowano „politykę historyczną” niechętnie. I to pomimo tego, że członkowie WKKP próbowali własne pojęcie odpartyjnić i zdekontekstualizować: „My nie wymyśliliśmy polityki historycznej - wspominał Karłowicz - my wymyśliliśmy nazwę, bo polityka historyczna istniała cały czas. W III RP była to tylko polityka historyczna transparentna, której nikt nie widział. Dla nich była to tylko historia" (Karłowicz, Łuczewski 2015). Następował tutaj podwójny ruch: z jednej strony, legitymizowano pojęcie PH jako pojęcie analityczne - następowało uabstrakcyjnienie tego pojęcia, które może odnosić się do wielu przypadków, a z drugiej delegitymizowano politykę historyczną uprawianą przez III RP, pokazując że to, co uznawano po prostu za historię, w istocie miało wymiar historyczno-polityczny. A zatem nawet uanalitycznienie PH w wydaniu WKKP prowadzić musiało do reakcji politycznych ze strony elit III RP. W konsekwencji naukowcy nie używali tego pojęcia, lecz co najwyżej opowiadali się po stronach konfliktu (zob. Wolff-Powęska 2007, Nijakowski 2008). Inaczej niż w Niemczech, pytanie nie brzmiało: czy i w jakiej formie polityka historyczna jest faktycznie realizowana, ale czy istnieje potrzeba (prawica) bądź nie (lewica) prowadzenia tego typu polityki. Pomijając kilka wyjątków, polscy naukowcy ograniczali się do polemicznych interwencji i nie rozwijali merytorycznych analiz na ten temat (zob. Kończal, Wawrzyniak 2011).

W obliczu powszechnej krytyki „polityki historycznej” ze strony liberalno-lewicowych polityków, naukowców i dziennikarzy dynamika semantyczna tego pojęcia przebiegała w dwóch kierunkach. Po pierwsze, polscy twórcy bronili jego użycia, podkreślając swój związek z demokracją 
i liberalizmem, a także sprzeciw wobec manipulacji historią i propagandy historycznej. W ten sposób wskazywali na to, że podzielają wartości swoich własnych krytyków. Już podczas inauguracji swojego projektu zdecydowanie zdystansowali się od „znanej z okresu komunizmu propagandy państwowej, zakłamującej oraz instrumentalizującej przeszłość" (Gawin, Kowal 2005: 13). Argumentowali, że „polityka historyczna nie jest w istocie rzeczy niczym więcej jak wyrażeniem przekonania o tym, że państwo nie może lekceważyć historii, że musi rozumieć, iż przeszłość nie jest zupełnie martwa, że nie przestała wywierać istotnego wpływu na nasze życie. Mówiąc o polityce historycznej, wskazujemy więc na odpowiedzialność państwa za stworzenie możliwości prowadzenia rzetelnych badań historycznych, za podtrzymywanie zainteresowania historią i za stałe toczenie batalii przeciw erozji pamięci zbiorowej" (Ujazdowski, Merta, Kostro 2006). Po drugie, zaczęto poszukiwać jego mniej obciążonych ekwiwalentów, takich jak „polityka pamięci” i „kultura pamięci” (niem. Erinnerungskultur). „Polityka pamięci” - którą obecnie popiera Robert Kostro (zob. Skibiński, Wiścicki, Wysocki 2011), dyrektor Muzeum Wolności, przemianowanego na Muzeum Historii Polski - wolna była od skojarzeń, że oto polityka wpływa na historię jako dyscyplinę akademicka - polityka może wpływać jedynie na pamięć o historii. Jednocześnie „kultura pamięci” zastępowała negatywne konotacje związane z polityka pozytywnymi konotacjami związanymi z kulturą, która nie ma nic wspólnego z odgórnymi manipulacjami, a raczej wyrasta naturalnie z oddolnych działań społeczeństwa obywatelskiego. Pod hasłem „kultury pamięci” przez kilka lat odbywały się polsko-niemieckie szkoły letnie prowadzone przez Muzeum Powstania Warszawskiego (Luczewski, Wiedmann 2011). W tym kierunku szli też politycy opozycyjni wobec PiS, jak np. wojewoda małopolski, reprezentujący Platformę Obywatelską, Stanisław Kracik (2011), który sięgnął do „kultury pamięci" jako oddolnej, tworzonej przez społeczeństwo obywatelskie praktyki, przeciwstawiając ja ,polityce historycznej” prowadzonej przez Prawo i Sprawiedliwość.

\section{/// Odpartyjnienie pojęcia}

W takiej sytuacji wielkim zaskoczeniem dla członków WKKP był fakt, że pojęcie $\mathrm{PH}$ zostało przejęte przez jego dotychczasowych krytyków (zob. Olszewski 2013). Najważniejszą rolę odegrał tutaj, jak się wydaje, historyk Paweł Machcewicz. Jego semantyczna strategia nie polegała już tyle na krytykowaniu samego pojęcia, ile na pokazywaniu nadużyć w stosowaniu 
tego pojęcia przez polską prawicę. Rola Machcewicza była tym większa, że tak jak Muzeum Powstania Warszawskiego stanowiło instytucjonalizację wizji polityki historycznej WKKP, tak Muzeum II Wojny Światowej, którego Machcewicz był pomysłodawcą i pierwszym dyrektorem, było instytucjonalizacja jego wizji polityki historycznej. Tak jak wizja WKKP została wzmocniona przez braci Kaczyńskich, tak wizja Machcewicza została wzmocniona przez Donalda Tuska, który potraktował Muzeum II Wojny Światowej jako okręt flagowy.

Preludium do walki już nie przeciw polityce historycznej, ale o jej właściwe rozumienie stanowił artykuł I Westerplatte, i Jedwabne, w którym Paweł Machcewicz polemizował wprost ze stanowiskiem Andrzeja Nowaka. Otóż nie zgadzał się on z Nowakiem, że „dumnie jako wspólnota możemy się czuć przy pomniku bohaterów Westerplatte, przy pomniku w Jedwabnem nie będziemy mogli odczuwać jednoczącej nas dumy z tego, że stać nas na wspólny wstyd z powodu tego, co tam się zdarzyło”. „Ja 10 lipca [podczas obchodów upamiętniających mord] - pisał - przy pomniku w Jedwabnem odczuwałem dumę z tego powodu, że Polacy potrafili godnie stawić czoło najtrudniejszym sprawom przeszłości” (2012b: 170). I dalej: „Odkrywanie całej prawdy o naszej przeszłości, przywracanie pełnego blasku rzeczom, z których słusznie powinniśmy być dumni, jak i zdzieranie zasłony ze spraw wstydliwych, które występują w historii każdego kraju, to najlepsza droga do budowania wspólnoty narodowej zakorzenionej w przeszłości, świadomej stojących za nią pokoleń. Wspólnoty, która nie będzie się bała konfrontacji z własną historia, nie będzie zaskakiwana odkryciami godzącymi w jej utrwalony wizerunek" (2012b: 171).

Jeszcze w 2006 roku na łamach „Gazety Wyborczej” Machcewicz dokonywał dekontekstualizacji polityki historycznej, podkreślając, że nie może być ona utożsamiana z praktykami pamięciowymi Prawa i Sprawiedliwości. Wywodził on, że „polityka historyczna to nic nowego”, gdyż prowadziła ją III RP i prowadza ją ,wszystkie nowoczesne państwa, demokratyczne czy dyktatorskie. Nie musi [ona] - choć oczywiście może - wiązać się z manipulacją i zagrożeniem dla wolności”. Kłopot z użyciem tego pojęcia polega - według niego - na tym, że zwolennicy IV RP używaja go ,jako obucha, którym się w wali w głowy obrońców III RP” (Machcewicz 2012b: 176). „Być może nowa «polityka historyczna» będzie lepsza, bardziej aktywna, mądrzejsza, ale będzie ona tylko kolejną odsłoną tego, co było zrobione wcześniej” (Machcewicz 2012b: 174). Za szczególnie dotkliwe uproszczenie zwolenników IV RP Machcewicz uznawał sprowadzanie polityki historycznej III RP do braku rozliczenia z przeszłością 
i pedagogiki wstydu (2012b: 189-194). Remedium proponowanym przez autora było odpolitycznienie sporu o politykę historyczną (zejście „z linii frontu między zwolennikami III i IV RP”): „«Polityka historyczna» oczywiście zawsze będzie przedmiotem sporów, ale ważne, by toczyły się one na gruncie pewnych wspólnie uznawanych celów i wartości - jak to się dzieje w przypadku polityki zagranicznej” (2012b: 176). „Politycy, precz od polityki historycznej" - konkludował w kolejnym artykule (2012b: 187).

W ten sposób Machcewicz konstruował projekt PH, który nie byłby rewolucyjno-konserwatywny. Istotne zatem nie jest to, czy państwo uprawia $\mathrm{PH}$, ale jaką PH uprawia; czy jest ona instrumentalizowana przez polityków, czy też pozostawiona w rękach społeczeństwa. Z podobnej strategii korzystał Robert Traba (2010), pisząc o polityce PiS jako „,nowej polityce historycznej”, czy Adam Michnik (2006), który zauważał, że polityka historyczna jest czymś powszechnym. Takiemu oddzieleniu PH od PH uprawianej przez prawicę służyło od samego początku podkreślanie przez WKKP, że proponują oni nie tyle PH, ile nową czy też nowoczesną politykę historyczną (Gawin, Kowal 2005).

Zgodnie ze swoją wizją Machcewicz zaproponował budowę Muzeum II Wojny Światowej. W artykule Muzeum zamiast zasieków pisał, że „jednym z wyzwań, z którymi będzie się musiał zmierzyć nowy rząd Donalda Tuska, jest problem upamiętnienia przez Niemcy powojennych przymusowych przesiedleń” (2012b: 249). Polską odpowiedzią na niemiecką politykę historyczną powinno być powstanie europejskiego muzeum: „W takim muzeum, którego dotąd nie ma w Europie, było miejsce na pokazanie pełnego doświadczenie wojny, w tym widzianej z perspektywy narodów, które doznały totalitaryzmu nie tylko nazistowskiego, ale i radzieckiego. Przymusowe wysiedlenia pokazane byłyby w nim w szerokim kontekście i rzeczywistych proporcjach, przede wszystkim jako nieuniknione - jak w 1945 roku uważali wszyscy politycy zwycięskiej koalicji - następstwa straszliwych niemieckich zbrodni” (2012b: 252). W takim Muzeum miałoby być miejsce i na doświadczenie chwały, cierpienia, i Westerplatte, i Jedwabne. Po latach, już jako dyrektor Muzeum II Wojny Światowej z nadania Platformy Obywatelskiej, Machcewicz mówił: „Jest dla mnie oczywiste, że polityka historyczna musi być związana z badaniami historycznymi - nie może sobie stawiać celów od nich oderwanych" (Machcewicz 2012a).

Z kolei sam Donald Tusk (2007) w swoim exposé deklarował: „będziemy chcieli przy pomocy polityki historycznej wzmocnić wizerunek Polski jako kraju, który w swojej historii zawsze miłował wolność i który wiedział, kiedy miał tę szansę, jak mądrze ją wykorzystać. W ostatecznym rachunku 
to właśnie taka polityka historyczna może być i będzie zasadniczym elementem oddziaływania Polski wobec naszych sąsiadów, także spoza Unii Europejskiej”. Był to moment przełomowy, kiedy to pojęcie przestało mieć charakter partyjny, a stało się pojęciem ponadpartyjnym (zob. też Olszewski 2013).

\section{/// Unaukowienie pojęcia}

W konsekwencji wydaje się, że również w Polsce pojawia się tendencja do unaukowienia pojęcia polityki historycznej. Autor eseju o polskiej polityce pamięci, Lech Nijakowski, utożsamiał politykę historyczną z ,trepanacją narodowa” w wykonaniu Prawa i Sprawiedliwości. Zarzucał jej promowanie romantycznej, wykluczającej, polsko-katolickiej ideologii narodowej, megalomanię, delegalizację PRL-u, antysowieckość, antygermanizm, antyeuropejskość, wyciszanie ciemnych plam historii i dążenie do rozliczenia przeciwników politycznych (Nijakowski 2008: 190-240). Te oceny bardzo przypominały początkową krytykę formowana przez naukowców niemieckich o orientacji lewicowej. Nijakowski jednak nie odrzucił ostatecznie pojęcia „polityki historycznej”, lecz próbował użyć go do analiz naukowych. Choć zatem pozostawało ono u niego pojęciem dynamicznym, mobilizującym, to jednocześnie dokonywał on jego dekontekstualizacji i używał w stosunku do odgórnych, państwowych praktyk wobec przeszłości. Dokonał on również próby udemokratycznienia go, pokazując, że nie tylko państwo czy prawica prowadza politykę historyczną, lecz także że lewica może - i powinna - prowadzić własną PH. Pojęciem przeciwstawnym wobec (złej) polityki historycznej nie była tu już dłużej nauka czy historia, lecz inna (dobra) polityka historyczna. Miała się ona wyróżniać tym, że jej domeną będzie nie zrytualizowana polityka, lecz racjonalna debata publiczna, że nie będzie centralistyczna, lecz regionalna, że nie będzie megalomańska, lecz krytyczna, nie militarystyczna, lecz pacyfistyczna. Pozostawać miała jednak cały czas pojęciem mobilizującym i atrakcyjnym (Nijakowski 2008: 254-262). Kolejny krok to dalsze zdemobilizowanie pojęcia „,polityki historycznej”. Tak uczynili Michał Luczewski i Paulina Bednarz-Luczewska (2011), którzy zdefiniowali „politykę historyczną” jako pojęcie przeciwstawne nie wobec historii/nauki czy (dobrej) polityki historycznej, lecz wobec „kultury pamięci”. Odwołując się do przywoływanych niemieckich autorów, określili PH jako oficjalną, odgórna, sterowaną przez państwo praktykę, której celem jest konstruowanie, rozpowszechnianie i zaszczepienie danych wyobrażeń przeszłości. Tak rozumiane aktywno- 
ści podejmowane przez państwo w celu ustanowienia konkretnej interpretacji historii należą do domeny polityki historycznej. W ten sposób przy wszystkich początkowych różnicach trajektoria semantyczna PH w Polsce upodobniła się ostatecznie do trajektorii w Niemczech (Kończal, Wawrzyniak 2011, Schmid 2009).

Bibliografia:

/// Assmann A. 2006. Der lange Schatten der Vergangenheit: Erinnerungskultur und Geschichtspolitik, C.H. Beck.

/// Assmann A. 2013. Ist die Zeit aus den Fugen? Aufstieg und Fall des Zeitregimes der Moderne, Carl Hanser Verlag.

/// Assmann J. 2008. Pamiéć kulturowa. Pismo, zapamietywanie i polityczna tożsamośc w cywilizacjach staro żytnych, tłum. A. Kryczyńska-Pham, Wydawnictwa Uniwersytetu Warszawskiego.

/// Assorodobraj-Kula N. 1995. „Żywa historia”: swiadomość bistoryczna: symptomy i propozycje badawcze, [w:] Sto lat socjologii polskiej. Od Supińskiego do Szczepańskiego, red. J. Szacki, PWN, s. 865-869. [Pierwodruk: 1963.]

/// Borowiec P. 2013. Czas polityczny po rewolucji. Czas w polskim dyskursie politycznym po 1989 roku, Wydawnictwo Uniwersytetu Jagiellońskiego.

/// Cat-Mackiewicz S. 1972. Kto mnie wołat, czego chciał..., PAX.

/// Chwedoruk R. 2007. Polityka historyczna a doświadczenia polskiej lewicy, „Przegląd Socjalistyczny” nr 5, s. 27-49.

/// Cichocki M. 1999. Ciagtośc $i$ zumiana. Czy konserwatyzm može nie być rewolucyjny?, Biblioteka „Więzi”.

/// Cichocki M. 2000. Moralistyczne podstawy amoralizmu, [w:] W obronie zdrowego rozsadku, red. M. Cichocki, T. Merta, Ośrodek Myśli Politycznej, s. 35-48.

/// Cichocki M. 2005. Wtadra i pamieć, Ośrodek Myśli Politycznej.

/// Cichocki M., Luczewski M. 2015. Wywiad przeprowadzony 15.12.

/// Cichocki M., Merta T., red. 2000. W obronie żdrowego rozsadku, Ośrodek Myśli Politycznej, s. 25-34. 
/// Czarnowski S. 1956. Drieła, t. I: Studia ₹ historii kultury, PWN.

/// Dudek A. 2011. Historia i polityka w Polsce po 1989 roku, [w:] Historycy i politycy. Polityka pamięci w III RP, red. P. Skibiński, T. Wiścicki, M. Wysocki, Wydawnictwo DiG, s. 33-57.

/// François E., Kończal K., Traba R., Troebst S., red. 2013. Geschichtspolitike in Europa seit 1989: Deutschland, Frankereich und Polen im internationalen Vergleich, Wallstein.

/// Frei N. 1999. Polityka wobec pržesztości: poczqutki Republiki Federalnej i przesztosí nazistowska, tłum. B. Ostrowska, Wydawnictwo Trio.

/// Friszke A., Gawin D., Stobiecki R., Wóycicki K., Wiścicki T. 2011. Panstwo wobec historii O sporach wokót polityki historycznej w ostatnich latach, [w:] Historycy i politycy. Polityka pamięci w III RP, red. P. Skibiński, T. Wiścicki, M. Wysocki, Wydawnictwo DiG, s. 11-32.

/// Gadamer H.-G. 2007. Prawda i metoda. Zarys hermenentylki filozoficznej, tłum. B. Baran, PWN.

/// Gawin D. 2007. Granice demokracji liberalnej, Ośrodek Myśli Politycznej.

/// Gawin D., Kowal P. 2005. Polska polityka historyczna, [w:] Polityka historyczna. Historycy - politycy - prasa, red. A. Panecka, Muzeum Powstania Warszawskiego, s. 11-13.

/// Hałas E. 1999. Transformacja w wyobraźni z̧biorowej, [w:] Imponderabilia wielkiej zmiany. Mentalność, wartości i wiezi spoteczne cz̧asón transformacji, red. P. Sztompka, PWN, s. 69-87.

/// Horolets A. 2006. Obrazy Europy w polskim dyskursie publicznym, Universitas.

/// Kaczyński J. 1996. Nowe państwo - rewolucja moralna, „Gazeta Polska”, 18.07.

/// Kaczyński J. 1998. Informacja rz̨adu o stanie bezpieczeñstwa publicænego w kraju. 2. Projekt apelu w sprawie bezpieczeństwa publicznego w miastach (druk nr 133). http://orka2.sejm.gov.pl/Debata3.nsf/118b9e577f3fceeac125746d0030d0fa/6b757ee1c397d320c1257491003e112e?OpenDocument; dostęp: 18.03.2016). 
/// Kalicka J., Witek P. 2014. Polityka historyczna, [w:] Modi memorandi. Leksykon kultury pamięci, red. M. Saryusz-Wolska, R. Traba, współpraca J. Kalicka, Wydawnictwo Naukowe Scholar, s. 378-387.

/// Karłowicz D. 2004. Koniec snu Konstantyna. Sžkice ż̀ycia codžiennego idei, Ośrodek Myśli Politycznej.

/// Karłowicz D. 2005. Pamiéć akesjologiczna a historia, [w:] Pamiéć i odpowiedżialność, red. R. Kostro, T. Merta, Ośrodek Myśli Politycznej, s. 35-41.

/// Karłowicz D. 2007. Arcyparadoks śmierci. Meczenenstwo jako kategoria filozoficzna-pytanie o dowodowa wartość meczeństwa, Fronda.

/// Karłowicz D., Łuczewski M. 2015. Wywiad przeprowadzony 27.10.

/// Kennedy M. 2002. Cultural Formations of Postcommunism: Emancipation, Transition, Nation, and War, University of Minnesota Press.

/// Konopczyński W. 1921. Od Sobieskiego do Kościusæki. Sžkice, drobiazgi, fraszki bistoryczne, Gebethner i Wolff.

/// Kończal K., Wawrzyniak J. 2011. Polskie badania pamiecioznawcze: tradycje, koncepcje, (nie)ciagłości, „Kultura i Społeczeństwo” nr 55(4), s. 11-63.

/// Kornaś J., red. 2010. Idea ustrojowa a ržeczywistość „IV Rzeczypospolitej”, Wydawnictwo Uniwersytetu Ekonomicznego.

/// Koselleck R. 2001. Semantyka bistoryczna, tłum. W. Kunicki, Wydawnictwo Poznańskie.

/// Koselleck R. 2009. Drieje pojeć. Studia z semantyki i pragmatyki jezyka spoteczno-politycznego, tłum. W. Kunicki, J. Merecki, Oficyna Naukowa.

/// Koselleck R. 2012. Warstwy czasu: studia z. metahistorii, tłum. K. Krzemieniowa, J. Merecki, Oficyna Naukowa.

/// Koselleck R. 2015. Krytyka i kryzys. Studium patogenezy świata mieszrzańskiego, tłum. J. Duraj, M. Moskalewicz, Fundacja Res Publica im. H. Krzeczkowskiego.

/// Kostro R., Ujazdowski K.M. 2005. Odzyskać pamię́, [w:] Pamieć i odpowied rialność, red. R. Kostro, T. Merta, Ośrodek Myśli Politycznej, s. 55-70.

/// Kostro R., Merta T., red. 2005. Pamięć i odpowiedzialność, Ośrodek Myśli Politycznej. 
/// Kracik S. 2011. Kultura pamięci, tožsamośc Małopolski, „Pressje” nr 26/27, s. $188-195$.

/// Krasnodębski Z. 1991. Upadek idei postępu, PIW.

/// Krasnodębski Z. 2003. Demokracja peryferii, Słowo/obraz/terytoria.

/// Kuczyński J. 1972. Indywidualność i ojczyzna. Filozoficzna problematyka kwestii narodowej, PIW.

/// Kunicki W. 1999. Wprowadrenie, [w:] C. Schmitt, Rewolucja konserwatywna w Niemczech 1918-1933, red. W. Kunicki, Wydawnictwo Poznańskie.

/// Kurczewska J. 2002. Patriotyzm(y) polskich polityków. Z badań nad swiadomościa liderów partyjnych lat dziewię́dziesiatych, Wydawnictwo IFiS PAN.

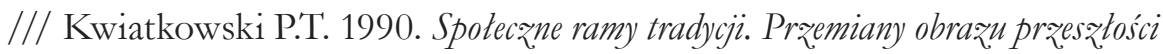
Marowsza Ptockiego w publikacjach regionalnych 1918-1988, IS UW.

/// Legutko P. 2014. Jedyne takie muzeum. Odzyskana pamiéć o Powstaniu Warszawskim, Znak.

/// Leszczyński A., oprac. 2006a. Czy państwo ma rzqdzić historia (debata z. udziałem Tomasza Merty, Jerzego Jedlickiego, Stanisława Gluzy), „Gazeta Wyborcza”, 16.06.

/// Leszczyński A. 2006b. Polityka bistoryczna. Wielki strach, „Gazeta Wyborcza", 07.04 .

/// Leszczyński A. 2007. Nadeszła „polityka bistoryczna”, „Gazeta Wyborcza", 09.01.

/// Lipiński A. 2009. Dyskursywne konstruowanie to ̇samości prawicy w warunkach podżialu postkomunistycznego, [w:] Wspótczesne partie polityczne. Wybrane problemy, red. T. Godlewski, M. Jastrzębski, I. Kapsa, D. Karnowska, A. Lipiński, Wydawnictwo Adam Marszałek, s. 186-242.

/// Lipiński A. 2012. Delegitymizacja III Rzeczypospolitej, budowanie partyjnej

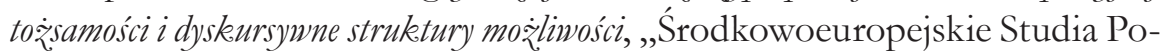
lityczne", t. 4, s. 75-92.

/// Lipski J.J. 1992 [1981]. Dwie ojczyzny, dwa patriotyzmy, [w:] Tunika Nessosa, PEN, s. 139-164.

/// Luczewski M., Bednarz-Luczewska P. 2011. Wie soll man Erinnerungskultur und Geschichtspolitik in Polen und Deutschland untersuchen?, [w:] Erinnerungs- 
kultur des 20. Jahrbunderts. Analysen deutscher und polnischer Erinnerungsorte, red. M. Łuczewski, J. Wiedmann, Peter Lang Verlag, s. 15-28.

/// Łuczewski M., Wiedmann J., red. 2011. Erinnerungskultur des 20. Jabrbunderts: Analysen deutscher und polnischer Erinnerungsorte, Peter Lang Verlag.

/// Machcewicz P. 2007. Jak polityka zasækodziła polityce historycznej, „Gazeta Wyborcza”, 14.09.

/// Machcewicz P. 2012a. Pamiéc historyczna bez politykón (rozmawia Adam Leszcryński), „Gazeta Wyborcza”, 29.03

/// Machcewicz P. 2012b. Spory o historie 2000-2011, Znak.

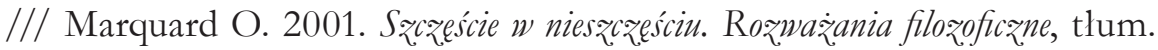
K. Krzemieniowa, Oficyna Naukowa.

/// Matyja R. 2009a. Konserwatyzm po komunizmie, Wydawnictwa Akademickie i Profesjonalne.

/// Matyja R. 2009b. Państwo, cæyli kłopot, Ośrodek Myśli Politycznej.

/// Meier Ch. 1987. Eröffnungsrede zur 36. Versammlung deutscher Historiker in Trier, 8. Oktober 1986, [w:] „Historikerstreit”. Die Dokumentation der Kontroverse um die Einzigartigkeit der nationalsozialistischen Judenvernichtung, red. R. Augstein, Pieper, s. 204-214.

/// Meier Ch. 2012. Powstanie polityczności u Grekón, tłum. M. Cichocki, Fundacja Świętego Mikołaja - Redakcja „Teologii Politycznej”.

/// Merta T. 2000. Nieodzowność konserwatyzmu, [w:] W obronie zdrowego rozsadku, red. M. Cichocki, T. Merta, Ośrodek Myśli Politycznej, s. 25-34.

/// Merta T. 2005. Pamięć i nadzieja, [w:] Pamieć i odpowiedzialność, red. R. Kostro, T. Merta, Ośrodek Myśli Politycznej, s. 87-113.

/// Merta T. 2008. Przyszłość można wybrać, opierajac się na pržesz̨tości (wywiad), „Nowe Kryteria”, nr 1, s. 9-20.

/// Michnik A. 2006. Polityka historyczna. Wariant rosyjski, „Gazeta Wyborcza", 28.09.

/// Nietzsche F. 1996. Niewczesne rozważania, tłum. M. Lukasiewicz, Znak.

/// Nijakowski L.M. 2008. Polska polityka pamieci: esej socjologiczny, Wydawnictwa Akademickie i Profesjonalne. 
/// Nowak A. 2001. Westerplatte czy Jedwabne, „Rzeczpospolita”, 1.08.

/// Nowinowski S., Pomorski J., Stobiecki R., red. 2008. Pamię́ i polityka historyczna. Doświadczenia Polski i jej sasiadów, Instytut Pamięci Narodowej, Komisja Ścigania Zbrodni przeciwko Narodowi Polskiemu.

/// Olszewski E. 2013. Pamié́ społeczna i polityka historyczna w programach polskich partii politycznych, „Środkowoeuropejskie Studia Polityczne”, nr 2, s. 67-97.

/// Ost D. 2007. Kleskea „Solidarności”: gniew i polityka w postkomunistycznej Europie, tłum. H. Jankowska, Muza.

/// Panecka A., red. 2005. Polityka historyczna, historycy - politycy-prasa, Muzeum Powstania Warszawskiego.

/// Roszkowski W. 2005. O potrzebie polskiej polityki historycznej, [w:] Pamię́ i odpowiedzialność, red. R. Kostro, T. Merta, Ośrodek Myśli Politycznej, s. 127-142.

/// Schmid H. 2009. Vom publizistischen Kampfbegriff zum Forschungskonzept. Zur Historisierung der Kategorie „Geschichtspolitik”, [w:] Geschichtspolitik und kollektives Gedächtnis. Erinnerungskulturen in Theorie und Praxis, V\&R Unipress, s. $53-75$.

/// Schmitt C. 1999. Epoka neutralizacji i polityzacji, [w:] Rewolucja konserwatywna w Niemczech 1918-1933, red. W. Kunicki, Wydawnictwo Poznańskie, s. $427-444$.

/// Schmitt C. 2000. Teologia polityczna i inne pisma, tłum. M. Cichocki, Znak.

/// Skibiński P., Wiścicki T., Wysocki M., red. 2011. Historycy i politycy. Polityka pamieci w III RP, Wydawnictwo DiG.

/// Stasik A. 2016. Konserwatyzm nielamentujacy: Warsqawski Klub Krytyki Politycznej 1996-2000, maszynopis.

/// Steinmetz W., red. 2007. „Politik”: Situationen eines Wortgebrauchs im Europa der Nenzeit, Campus.

/// Szacka B. 2006. Czas przeszły, pamié́, mit, Wydawnictwo Naukowe Scholar.

/// Szacka B., Sawisz A. 1990. Czas præeszły i pamię́ spoteczna: præemiany świadomości historycznej inteligencji polskiej, 1965-1988, IS UW. 
/// Szacki J. 1965. Kontrrewolucyjne paradoksy. Wirje swiata francuskich antagonistón Wielkiej Rewolucji 1789-1815, PWN.

/// Szacki J. 1971. Tradycja. Przeglad problematyki, PWN.

/// Szacki J. 1991. Dylematy historiografii idei oraz inne szkice i studia, PWN.

/// Szacki J. 1994. Liberalizm po komunizmie, Znak.

/// Śpiewak P. 2003. Koniec złtudzeń, „Rzeczpospolita”, 23.01.

/// Śpiewak P. 2005. Pamiéć po komuniżie, Słowo/obraz/terytoria.

/// Tarkowska E., red. 1996. O crasie, politykach i czasie politykón, Wydawnictwo IFIS PAN.

/// Tarrow S., McAdam D. 2008. Zmiana skali, [w:] Dynamika życia spotecznego. Wspótczesne koncepcje ruchów społecznych, red. K. Gorlach, P. H. Mooney, Scholar, s. 347-373.

/// Taubes J. 2010. Teologia polityczna śnietego Pawła. Wykłady wygłoszone w Ośrodku Badań Ewangelickiej Wspólnoty Studyjnej w Heidelbergu 23-27 lutego 1987 roku, tłum. M. Kurkowska, Wydawnictwo Naukowe PWN, Fundacja Świętego Mikołaja. Redakcja „Teologii Politycznej”.

/// Tokarz T. 2011. Koncepcja „polityki historycznej” w myśli konserwatystów polskich, „Kultura i Historia”, t. 19. http://www.kulturaihistoria.umcs.lublin. pl/archives/2468; dostęp: 13.02.2017

/// Traba R. 2010. Polityka wobec historii, „Teksty Drugie” nr 1/2, s. 300-319.

/// Trentowski B. 1843. Stosunek filozofii do cybernetyki, czyli sætuki rz̨adzenia narodem: ržecz o trésí politycznej, nakładem Księgarni J. K. Żupańskiego.

/// Troebst S. 2014. Geschichtspolitik, Docupedia-Zeitgeschichte. http://docupedia.de/zg/Geschichtspolitik?oldid=106422; dostęp: 18.01.2016

/// Tusk D. 2007. Expose, „Gazeta Wyborcza”, 23.11.

/// Ujazdowski K.M., Merta T., Kostro R. 2006. Polityka historyczna i jej wrogowie, „Gazeta Wyborcza”, 06.04.

/// Voegelin E. 1992. Nowa nanka polityki, tłum. P. Śpiewak, Aletheia.

/// Walicki A. 1970. Filozofia a mesjanizm. Studia z driejón filozofii i myśli spoteczno-religijnej romantyzmu polskiego, PIW.

/// Walicki A. 2011. Polska, Rosja, marksiz̨m, Universitas. 
/// Wolff-Powęska A. 2007. Polskie spory o bistorie i pamiéc. Polityka bistoryczna, „Przegląd Zachodni” nr 66(1), s. 3-44.

/// Wolff-Powęska A. 2011. Pamię́ - bržemie i unolnienie. Niemcy wobec ną̧istowskiej przesz̨ości (1945-2010), Wydawnictwo Zysk i S-ka.

/// Żakowski J. 1994. Cośw Polsce pekłto, cośsie skończyto, „Gazeta Wyborcza”, 16.04 .

/// Zychlińska M., Fontana E. 2016. Museal Games and Emotional Truths: Creating Polish National Identity at the Warsaw Rising Museum, „East European Politics \& Societies", nr 30(2), s. 235-269.

/// Żychlińska M. 2009. Mureum Powstania Warsqawskiego jako webikut polskiej pamieci zbiorowej, „Kultura i społeczeństwo” nr 53(3), s. 89-114.

\section{/// Abstrakt}

Tekst podejmuje analizę semantyczna pojęcia polityki historycznej, które stanowi ważny klucz do zrozumienia przemian społecznych III RP i nowoczesności w ogóle. Pojęcie polityki historycznej zostało spopularyzowane pod koniec lat 90. przez intelektualistów związanych z Warszawskim Klubem Krytyki Politycznej (WKKP) i uzyskało rezonans jako jeden z filarów rewolucji semantycznej Prawa i Sprawiedliwości z lat 2003-2005. Przejawem instytucjonalizacji tego pojęcia jest otwarte w 2004 roku Muzeum Powstania Warszawskiego, którego współtwórcami byli członkowie WKKP. Pojęcie polityki historycznej pojawiło się w kontekście krytyki nowoczesności i charakterystycznego dla niej zerwania z przeszłością na rzecz wyboru przyszłości. Miało ono zarazem wymiar nowoczesny: dążąc do rewolucyjnej przemiany rzeczywistości, wybierało przyszłość, nie zrywając z przeszłością, lecz do niej powracając. Artykuł odwołuje się także do prehistorii tego pojęcia w filozofii dziejów Bronisława Trentowskiego i Augusta Cieszkowskiego, wskazuje na głębokie warstwy znaczeniowe polityki i historii.

Słowa kluczowe:

polityka historyczna, nowoczesność, semantyka historyczna, wędrówka pojęć, Koselleck 


\section{/// Abstract}

This paper undertakes a semantic analysis of the concept of historical politics, which is key to understanding the social transformations of the Third Republic and modernity in general. The idea of historical politics was popularized by the end of the 1990s by intellectuals associated with the Warsaw Club of Political Criticism (WKKP) and gained resonance as one of the cornerstones of the semantic revolution of the Law and Justice Party in the years 2003-2005. The institutionalization of this concept was the opening in 2004 of the Warsaw Rising Museum, whose co-creators were members of WKKP. The concept of historical politics appeared in the context of a critique of modernity and its characteristic break with the past to choose the future. At the same time, the concept of historical politics had a modern dimension: in the pursuit of a revolutionary transformation of reality, it chose a future that was not a break from the past, but a return to it. This article also references the prehistory of the concept in Bronisław Trentowski's and August Cieszkowski's philosophy of history, showing the deep layers of meaning of politics and history.

Keywords:

politics of history, modernity, historical semantics, travelling concepts, Koselleck 